Artigo

\title{
Movimento LGBT e partidos políticos no Brasil
}

\section{Gustavo Gomes da Costa Santos ${ }^{1}$}

Resumo: O presente texto busca analisar as relações e tensões entre o movimento LGBT e os partidos políticos no Brasil pós-redemocratização. O texto está organizado em três partes. Na primeira parte, explorar-se-á as relações e tensões entre ativistas homossexuais e os partidos políticos de esquerda desde a emergência do movimento político de homossexuais no contexto da redemocratização política até a eleição do ex-presidente Luiz Inácio Lula da Silva (2003-2011). Na segunda parte, apresentar-se-á uma radiografia dos partidos políticos brasileiros contemporâneos a luz de seus posicionamentos em relação à questão da livre orientação sexual/identidade de gênero. Na terceira parte do texto, analisar-se-á os posicionamentos dos partidos políticos no Congresso Nacional desde a década de 1980 no que diz respeito às propostas de lei garantindo direitos à população LGBT. Os dados analisados visam subsidiar a reflexão acerca de como a temática dos direitos LGBT tem sido (ou não) contemplada pelas organizações partidárias e por seus membros no Congresso Nacional e quais são os limites e possibilidades da defesa dos direitos sexuais de LGBT no contexto da política institucional brasileira.

Palavras-chave: Movimento LGBT; partidos políticos; LGBT; setoriais LGBT; orientação sexual; projeto de lei pró-LGBT.

\section{LGBT Movement and political parties in Brazil}

Abstract: The present article aims to analyse the relationships and tensions between LGBT movement and political parties in post-redemocratisation Brazil. The text is organised in three parts. In the first part, I explore the relationships and tensions between lesbian and gay activists and leftist political parties, since the emergence

${ }^{1}$ Departamento de Sociologia - Universidade Federal de Pernambuco (UFPE) - Recife - Brasil gustavo.gomescosta@ufpe.br 
of lesbian and gay political movement until the election of former president Luis Luis Inácio Lula da Silva (2003-2011). In the second part, I present a radiography of Brazilian Contemporary political parties according to their positions related to the issue of free sexual orientation/gender identity. In the third part, I analyse the position of political parties in National Congress since the 1980s regarding bills that would guarantee rights to the LGBT population. The analysed data will shed light on the debate of whether (or not) partisan organisation and their members in Nation Congress address LGBT rights. The data will also support the understating of the limits and possibilities for advocating LGBT sexual rights in the context of Brazilian institutional politics.

Keywords: LGBT movement; political parties; LGBT; LGBT affiliated to political parties groups; sexual orientation; pro-LGBT bills.

\section{Introdução}

A luta por direitos iguais promovida por lésbicas, gays, bissexuais, travestis e transexuais (também identificados pela sigla LGBT) tem ganhado grande visibilidade no debate público e nos meios de comunicação de massa no Brasil. Neste princípio de século, as Paradas do Orgulho LGBT têm se espalhado por diversas partes do país, sendo a Parada organizada anualmente na cidade de São Paulo a maior do gênero no mundo. As Paradas do Orgulho LGBT, juntamente com outras formas de mobilização do movimento LGBT, a exemplo de passeatas e dos "beijaços"2", têm auxiliado na divulgação de situações de discriminação e violência direcionada a esse segmento da população, desvelando a intolerância ainda reinante na cultura brasileira em relação a identidades sexuais discordantes do modelo heterossexual hegemônico.

A cada dia, essas demandas vêm também ganhando espaço no âmbito da política institucional, com alguns ganhos relevantes em termos de reconhecimento legal e de garantia de direitos. A decisão do Supremo Tribunal Federal (STF) proferida em maio de 2011 representa importante marco na luta pela extensão de direitos conjugais aos casais homoafetivos ${ }^{3}$. Da mesma forma, o plano "Brasil sem Homofobia”, elaborado no governo do então presidente Luiz Inácio Lula da Silva (2003-2011), foi a primeira política pública direcionada especificamente à

\footnotetext{
${ }^{2}$ Inspirados nos "Kiss-in" organizados pelo movimento LGBT norte-americano, os beijaços são uma forma de protesto utilizada por diversos ativistas LGBT pelo mundo. Nesse tipo de ação, ativistas LGBT beijam-se em espaços públicos ou privados onde ocorreram episódios de discriminação contra homossexuais, de forma a reivindicar o direito à livre expressão da sexualidade.

${ }^{3}$ Criado pela ex-desembargadora e atual presidente do IBDFAM, Maria Berenice Dias, o termo homoafetivo visava enfatizar a questão do afeto como parte constitutiva dos laços conjugais existente entre as pessoas do mesmo sexo. O termo é amplamente utilizado por vários setores do movimento LGBT e também por diversos operadores do Direito.
} 
promoção e defesa dos direitos de LGBT na América Latina. Essas vitórias legais representam importantes avanços na luta pela cidadania plena de LGBT.

Contudo, esses ganhos são limitados, dado que o Brasil ainda não possui nenhuma lei em âmbito federal que garanta explicitamente direitos à população LGBT. Em grande medida isso ocorre devido à intensa oposição de setores conservadores (em sua maioria com vinculações a entidades religiosas) dentro do Congresso Nacional, que têm evitado a aprovação de leis favoráveis as chamadas "minorias sexuais". A ação desses setores tem recentemente evoluído da mera obstrução de iniciativas de leis favoráveis a LGBT para a proposição de legislação que claramente restringe direitos a essa população. Além de promover projetos de lei contrários aos direitos sexuais no âmbito do poder Legislativo, esses setores conservadores têm atuado firmemente no sentido de bloquear ações de governo que promovam a cidadania LGBT. Exemplo disso ocorreu em maio de 2011 quando do lançamento do material desenvolvido por ONGs em parceria com o Ministério da Educação (MEC) para capacitação de professores da rede pública de ensino médio para tratar da temática da diversidade sexual ${ }^{4}$. Tachado por opositores de "kit gay", a distribuição do material foi suspensa pela presidente Dilma Rousseff (PT), sob alegação de que não seria adequado para tratar do assunto. Contudo, vários meios de comunicação destacaram a pressão de parlamentares da Frente Parlamentar Evangélica (FPE) para que a presidente vetasse o material, em troca do apoio dos parlamentares da Frente à aprovação dos projetos de lei de interesse do poder Executivo. Em 2010, o chamado "lobby religioso" aproveitou a "oportunidade" do segundo turno das eleições presidenciais ${ }^{5}$ para pressionar os dois candidatos ainda na disputa (Dilma Rousseff e José Serra) a comprometerem-se publicamente com a sua agenda que incluiria a recusa à descriminalização do aborto, à aprovação do projeto de lei tornando a homofobia crime, tal como o racismo, e ao reconhecimento do "casamento gay". Em um cenário de acirrada disputa eleitoral, os dois candidatos cederam às pressões do "voto evangélico" e se comprometeram publicamente que, se eleitos, seriam contrários à legalização da interrupção voluntária da gravidez e à criminalização da violência contra os homossexuais (Nery; Falcão, 2010). Esses dois fatos demonstram os diversos desafios enfrentados por ativistas da promoção dos direitos sexuais no âmbito da política institucional.

O trabalho conjunto de ativistas e grupos do movimento LGBT com instâncias estatais se intensificou nos últimos anos, principalmente após a chegada do Partido dos Trabalhadores (PT) ao poder. Contudo, o engajamento do movimento LGBT junto ao Estado brasileiro data da década de 1980, quando ativistas do então

\footnotetext{
${ }^{4} \mathrm{O}$ "Escola sem Homofobia" é composto por apostilas e material audiovisual que visa capacitar professores do ensino médio da rede pública a lidar com a questão da diversidade sexual. A confecção do material foi realizada em parceria entre o MEC e atores da sociedade civil e é uma das ações previstas no plano "Brasil sem Homofobia”.

${ }^{5}$ Tida como favorita à sucessão do presidente Luiz Inácio Lula da Silva, a candidata Dilma Rousseff (PT) não obteve a maioria dos votos para ser eleita no primeiro turno das eleições, a despeito dos resultados de diversas pesquisas eleitorais afirmarem o contrário.
} 
movimento homossexual brasileiro (MHB) se engajaram na defesa da proposta de inclusão do termo "orientação sexual" no rol de critérios de não discriminação na Constituinte em 1987 (Câmara, 2002; Santos, 2011). A proposta foi rejeitada pelos constituintes e voltou a ser debatida quando da Revisão Constitucional realizada entre 1993 e 1994, sendo mais uma vez derrubada pelo plenário do Congresso Nacional. Desde então, diversos projetos de lei pró-LGBT foram apresentados por parlamentares brasileiros, a exemplo da Parceria Civil Registrada (PCR $)^{6}$ e da criminalização da homofobia ${ }^{7}$. Este último projeto chegou a ser aprovado em votação simbólica no plenário da Câmara dos Deputados em 2006, sendo remetido ao Senado Federal, onde sofreu intensa oposição de senadores vinculados à FPE e acabou arquivado em 2011.

O prematuro envolvimento do movimento LGBT brasileiro com instâncias estatais decorre, em grande medida, do trabalho conjunto entre ativistas homossexuais e agremiações partidárias, principalmente no campo da esquerda. Desde o fim da década de 1970, diversos ativistas homossexuais militavam em grupos partidários e muitos deles contribuíram, por exemplo, para a fundação do PT em 1980. Todavia, a relação entre o movimento homossexual com essas organizações partidárias tem sido caracterizada por diversas tensões e conflitos. Ao longo da história do movimento LGBT, diversos "impasses" e "rachas" ocorridos no seio da militância homossexual tinham como uma das razões a questão da autonomia do movimento frente aos partidos políticos. O receio de parte da militância homossexual da instrumentalização (identificada no jargão da militância como "cooptação") do movimento para a consecução de interesses político-partidários permeou vários dos conflitos internos ao ativismo LGBT brasileiro.

O presente texto busca analisar as relações e tensões entre o movimento LGBT e os partidos políticos no Brasil. Os dados apresentados neste artigo advêm majoritariamente das minhas pesquisas de mestrado e doutorado realizadas entre os anos de 2004 e 2011. O texto se organiza em três partes. Na primeira parte, explorar-se-á as relações e tensões entre ativistas homossexuais e os partidos políticos de esquerda (principalmente com o PT) desde o surgimento do movimento organizado de homossexuais no contexto da redemocratização política até a eleição do ex-presidente Luiz Inácio Lula da Silva (2003-2011). Na segunda parte, apresentar-se-á uma radiografia dos partidos políticos brasileiros contemporâneos à luz de seus posicionamentos em relação à questão da livre orientação sexual/identidade de gênero. Na terceira parte do texto, analisar-se-ão os posicionamentos dos partidos políticos no Congresso Nacional desde a década de 1980 no que diz respeito às propostas de lei garantindo direitos à população LGBT. A segunda e terceira partes apresentam dados preliminares de uma pesquisa em processo de formatação sobre as políticas LGBT e o Estado no Brasil do século XXI intitulada "Diversidade sexual e política institucional no Brasil contemporâneo",

${ }^{6}$ PL 1.151/1995, de autoria da deputada Marta Suplicy (PT-SP).

7 PL 5.003/2001, de autoria da deputada Iara Bernardi (PT-SP). 
que está sendo desenvolvida junto ao Programa de Pós-Graduação em Sociologia (PPGS) da Universidade Federal de Pernambuco (UFPE).

A hipótese que norteia esse trabalho é a de que não se pode traçar uma equivalência direta entre as clivagens partidárias e a defesa nos direitos LGBT no Brasil. Há uma tendência a que membros de partidos de esquerda ${ }^{8}$ sejam mais "simpatizantes" à causa LGBT, não só pela vinculação histórica do movimento LGBT aos movimentos de esquerda, mas também em virtude do apoio de diverso(a) $s$ parlamentares de esquerda às pautas dos grupos sociais ditos "minoritários" (a exemplo das mulheres, negros, indígenas etc.). No entanto, observa-se que vários membros de partidos considerados de "centro" e de "direita" tanto votaram a favor de propostas de legislação favoráveis a LGBT quanto apresentaram propostas de leis favoráveis a esse segmento da população. Além disso, observa-se tendência recente de alguns desses partidos, a exemplo do PSDB, PMDB e PTB, a fundarem setoriais LGBT em suas estruturas partidárias.

\section{Movimento LGBT e partidos políticos no Brasil: um breve histórico}

A homossexualidade permeou o imaginário social brasileiro desde os tempos da colonização portuguesa. Acusados de cometer o pecado infame da sodomia ${ }^{9}$, muitos indivíduos foram perseguidos pela Igreja Católica e punidos com a pena de morte por supostamente praticarem atos homossexuais (Trevisan, 2004; Mott, 1989). Com a independência política em 1822 e a aprovação do Código Criminal do Império em 1830, a homossexualidade foi descriminalizada no Brasil, o que não significou a aceitação dessa prática sexual pela sociedade e pelo Estado. Ao longo do século XIX e nas primeiras décadas do século XX, indivíduos com práticas homoeróticas foram alvos do assédio da população, dos órgãos médicos e das instituições policiais (Green; Polito, 2006). Foi a partir das décadas de 1940 e 1950 que a homossexualidade no Brasil começou a ganhar visibilidade pública para além das páginas policiais dos jornais. As intensas modificações sociais que o Brasil experimentava, dentre elas a intensa urbanização e industrialização, possibilitou a emergência de diversos locais de sociabilidade homossexual, principalmente no Rio de Janeiro e em São Paulo. Criaram-se assim diversas redes de sociabilidade e no ano de 1968 foi fundado o Snob, primeiro periódico voltado ao público homossexual (Green, 2000).

Apesar da existência de uma subcultura homossexual relativamente bem desenvolvida nos dois principais centros urbanos do país já na década de 1960, é com a fundação do grupo Somos, em 1978, na cidade de São Paulo, que tem início a luta propriamente política dos homossexuais no Brasil (Macrae, 1990; Green,

\footnotetext{
${ }^{8}$ Para uma discussão mais teórica sobre as definições de esquerda e de direita e seus impactos no eleitorado, vide Bobbio (1995) e Singer (1999).

${ }^{9}$ O pecado da sodomia era considerado crime de lesa majestade (isto é, contra a pessoa do Rei) e passível de punição com a morte de acordo com o Livro V, Título XIII das Ordenações Filipinas, vigentes em Portugal e nos seus domínios desde o século XVI.
} 
2000; Trevisan, 2004). Em meio ao processo de abertura do regime militar, os homossexuais buscaram pela primeira vez no país politizar a homossexualidade, a fim de romper com os limites do gueto homossexual. Nesta época, o Brasil passava por diversas mudanças políticas. Emergiram vários movimentos sociais que se mobilizavam contra o autoritarismo e pela melhoria de vida da maioria da população que ficou excluída dos ganhos econômicos do "milagre brasileiro". Aliado à grande mobilização política, o país passava por um momento de transformações culturais, no qual os ideais da contracultura contestavam os valores culturais hegemônicos, dentre eles os rígidos códigos sexuais e a heterossexualidade normativa (Green, 2000).

Nesse contexto de ampla contestação política e cultural ao status quo surge o jornal Lampião da Esquina (1978), um dos expoentes da chamada imprensa "nanica”. Ao criticar o autoritarismo presente tanto nas instituições políticas como na própria sociedade, o Lampião levantou a questão da homossexualidade em seus aspectos político, existencial e cultural. O jornal converteu-se no grande divulgador das ideias e discussões do grupo Somos e também de outros grupos do incipiente movimento homossexual, embora essa relação muitas vezes tenha sido conflituosa (Macrae, 1990).

Nesta "primeira onda" do movimento homossexual (Facchini, 2005) havia uma ampla rejeição a qualquer forma de autoritarismo. Com um discurso de autonomia em relação aos partidos políticos e ao Estado, o grupo Somos, além de lutar contra o machismo, propunha um modelo igualitário de identidade sexual que rejeitava os modelos hierárquicos de relações sexuais/afetivas presentes na cultura brasileira (Fry, 1982) e reivindicava uma identidade homossexual na qual se identificariam todos aqueles que eram vítimas da discriminação e do preconceito (Macrae, 1990).

Apesar da ênfase à igualdade dada pelos seus membros, a grande heterogeneidade do grupo demonstrava importantes divergências internas, que o levariam a uma cisão interna. Dentre elas, tínhamos as reivindicações das militantes lésbicas por maior representatividade dentro do grupo e por um aprofundamento das discussões sobre suas especificidades, haja vista sua condição de duplamente discriminadas (por serem mulheres e homossexuais). Além disso, as lésbicas acusavam os membros homossexuais masculinos do grupo de apresentarem, em muitas situações, uma postura machista e misógina (Macrae, 1990).

Outra divergência importante referia-se às visões distintas sobre as atividades e os rumos do Somos, que estavam fortemente relacionadas à vinculação ou não do ativismo homossexual às organizações partidárias de esquerda. Desde as primeiras articulações para organizar o movimento homossexual no Brasil, diversos membros da organização trotskista Convergência Socialista (CS) desempenharam papel importante na politização da homossexualidade. A organização foi a primeira a criar uma Facção Gay vinculada à sua estrutura e trazer o tema da discriminação dos homossexuais para o debate político no âmbito da esquerda (Dehesa, 2007). É bom lembrar que na década de 1970 a homossexualidade ainda era vista por 
grande parte da esquerda internacional como símbolo da "decadência burguesa" das classes médias e altas (Green, 2003). Além disso, muitos ativistas acusavam os chamados movimentos identitários (a exemplo dos homossexuais, de negros e de mulheres) de fragmentar as classes trabalhadoras com suas demandas específicas e "secundárias", dispersando os setores de esquerda da luta "maior" para o fim do capitalismo. Os militantes homossexuais vinculados à esquerda partidária tinham um duplo desafio: de um lado convencer seus "camaradas" de esquerda da importância de incluir a luta contra a opressão sexual como parte fundamental da luta por uma transformação global da sociedade; de outro, demonstrar a seus companheiros de ativismo homossexual que a vinculação da causa homossexual à luta da esquerda não colocaria em xeque a autonomia do movimento frente às organizações partidárias.

No caso específico do Somos, MacRae (1990) analisa o "racha" ocorrido no grupo depois dos debates em torno da participação ou não de seus membros nas manifestações do $1^{\circ}$ de Maio organizadas pelo movimento sindical. Na ocasião ficaram explícitas duas posições contrárias em torno dos rumos a serem tomados pelo Somos. Uma delas era representada por aqueles ativistas conhecidos como "anarquistas" que enfatizavam a autonomia do grupo e a necessidade de reforçar as atividades voltadas ao aspecto afetivo-emocional e de construção de uma "consciência homossexual". Os ativistas anarquistas criticavam ferozmente aquilo que viam como tentativa de "cooptação" do grupo por membros de organizações de esquerda "infiltrados" no Somos. Na outra posição estavam aqueles ativistas homossexuais com atividades junto à militância de esquerda, que enfatizavam a necessidade de estabelecer alianças do movimento homossexual com outros movimentos sociais, vinculando a luta homossexual à luta geral pela transformação da sociedade (Macrae, 1990; Trevisan, 2004). Muitos desses militantes vão desempenhar papel fundamental na fundação do PT em 1980 e na inclusão da defesa dos direitos dos homossexuais no programa do partido. Além disso, os esforços pioneiros desses ativistas homossexuais em sensibilizar as lideranças de esquerda da importância da não discriminação da população LGBT serão fundamentais para o apoio futuro de parlamentares do PT à aprovação de leis pró-LGBT (Green, 2003).

O racha ocorrido no grupo Somos em 1980 iniciou o processo de desarticulação do movimento homossexual em São Paulo, desarticulação essa que se intensificará com o advento da epidemia de Aids. Observou-se a reconfiguração dos grupos do movimento homossexual brasileiro, com a mudança da sua concentração geográfica do eixo São Paulo-Rio para Rio-Nordeste. Nesta "segunda onda" do movimento homossexual encontramos uma diminuição considerável no número de grupos, uma postura menos refratária à institucionalidade político-partidária e mais vinculada a uma ação pragmática, com o protagonismo do Grupo Gay da Bahia (GGB) e do grupo Triângulo Rosa-RJ (Câmara, 2002; Simões; Facchini, 2009). Dentre essas ações encontramos a participação do presidente do Triângulo Rosa, João Antônio Mascarenhas, nos debates da Assembleia Nacional Constituinte 
(ANC), com vistas a sensibilizar os parlamentares a incluir o termo "orientação sexual" nas proibições de discriminação enumeradas no artigo $5^{\circ}$ da Constituição (Câmara, 2002). A proposta teve o apoio de vários parlamentares de esquerda, com destaque para a atuação do então deputado constituinte José Genoíno (PT-SP), responsável pela inclusão da proposta para votação em plenário. A proposta acabou não sendo contemplada no texto final.

Outra importante característica da "segunda onda" do movimento LGBT foi a atuação de ativistas homossexuais junto às instâncias partidárias de esquerda. Exemplo disso é a militância de Herbert Daniel. Ex-guerrilheiro e exilado político durante o regime militar, Daniel desempenhou papel fundamental na promoção de debates internos ao PT sobre as temáticas de gênero e sexualidade. Um dos primeiros candidatos assumidamente homossexual e com militância política na área de direitos sexuais, sua campanha a deputado estadual no Rio de Janeiro em 1986 centrou-se em temas alternativos, como a homossexualidade, defesa dos direitos de soropositivos e preservação ambiental. Junto com Fernando Gabeira e Alfredo Sirkis, deixam o PT para fundar o Partido Verde (PV) em 1989.

No caso específico do PT, a militância de homossexuais nas instâncias partidárias não significou, contudo, que o tema da livre orientação sexual foi "abraçado" por todos os setores do partido. Exemplo da dificuldade em vincular a luta pela livre orientação sexual às demandas da esquerda foi demonstrado durante a escolha do companheiro de chapa na primeira candidatura à presidência de Luiz Inácio Lula da Silva em 1989. O primeiro nome escolhido pela convenção do partido foi o de Fernando Gabeira. Contudo, sua vinculação a temas polêmicos, como a descriminalização do uso da maconha, e sua postura não suficientemente "viril" contribuíram para o rechaço de seu nome para a candidatura à vice-presidência (Dehesa, 2007). Embora nunca tenha participado formalmente do movimento homossexual, vários militantes do PT e de outros partidos de esquerda acreditavam que a imagem de Gabeira estaria muito vinculada às minorias sexuais e poderia prejudicar a candidatura petista junto ao eleitorado (Trevisan, 2004). Até mesmo a criação de um setorial LGBT dentro da estrutura partidária do PT paulista, supostamente mais "liberal" do que outros estados brasileiros, sofreu várias oposições, sendo viabilizada apenas em 1992 (Green, 2003).

Todos esses fatos demonstram a dificuldade da esquerda partidária em contemplar a luta contra a discriminação dos homossexuais como parte constitutiva de seu projeto de transformação social. Da mesma forma, ativistas homossexuais enfrentaram dificuldades em compatibilizar sua militância política na esquerda ao ativismo homossexual. No caso específico de São Paulo, embora a rearticulação do movimento na década de 1990 tenha contado com a contribuição do Núcleo de Gays e Lésbicas do PT (NGLPT), as relações entre o ativismo homossexual e 0 partido foram permeadas por tensões. Em 1996, juntamente com outras diversas candidaturas gays no país, foi lançada a primeira candidatura de um homossexual assumido à Câmara Municipal de São Paulo pelo PT (Giacomini, 1996). Mesmo com o apoio da então deputada Marta Suplicy e de setores do movimento LGBT 
paulistano, a candidatura não obteve sucesso, em parte devido à falta de apoio do NGLPT, que acusava o seu proponente, então membro do Centro Acadêmico de Estudos Homoeróticos da USP (CAEHUSP), de "extremo personalismo" (Santos, 2006). Nesta mesma eleição, a candidata Kátia Tapety foi eleita vereadora na cidade de Colônia do Piauí (PI), sendo considerada a primeira travesti a ser eleita para um cargo eletivo (Santos, 2015).

Além disso, em 2002 o movimento LGBT em São Paulo vivenciou outro "racha" interno. Em minha pesquisa de mestrado realizada junto às lideranças homossexuais da cidade de São Paulo (Santos, 2006), identifiquei que uma das razões do conflito estava na vinculação da Associação da Parada do Orgulho GLBT de São Paulo (APOGLBT-SP) a partidos políticos, em especial ao PT. Embora o estopim do conflito tenha sido o questionamento da prestação de contas da diretoria da APOGLBT a respeito de um financiamento, para capacitação de ativistas, fornecido pelo Comitê Técnico da Diversidade (Central de Notícias MixBrasil, 2002a, 2002b), um dos pontos principais do racha girou em torno da candidatura a deputado federal do então presidente da APOGLBT, filiado ao PT. Parte da Diretoria da APOGLBT acusou o então presidente e outros ativistas LGBT filiados ao partido de supostamente fazerem uso "político-eleitoreiro" da grande visibilidade política promovida pela Parada de São Paulo, que na ocasião contou com a presença de meio milhão de pessoas, colocando assim em xeque a autonomia do movimento LGBT na cidade (Santos, 2006).

É interessante notar que os conflitos internos ao ativismo LGBT em torno da vinculação do movimento a partidos políticos não se restringem ao movimento LGBT paulistano. Em 2005, o movimento LGBT de Porto Alegre (RS) vivenciou semelhante "racha", quando da organização da Parada Livre na cidade. O grupo Nuances, que havia sido responsável pela organização da Parada Livre de Porto Alegre desde 1997, acusou o Fórum LGBT de Porto Alegre de querer "partidarizar" o evento, utilizando-o supostamente para promover lideranças homossexuais vinculadas ao PT. Já o Fórum LGBT acusou o Nuances de querer supostamente monopolizar a organização da Parada, dificultando a participação de outros grupos do movimento LGBT local na organização do evento. O resultado do conflito foi a realização de duas Paradas na cidade (Parada Livre e Parada do Orgulho GLBT) em 2005 (Böer, 2005).

Mais recentemente, em 2011, o episódio da suspensão, pela presidente Dilma Rousseff, da distribuição do "kit anti-homofobia" gerou críticas por parte do setorial LGBT Nacional do PT. Em uma carta aberta à presidente divulgada nos meios de comunicação, o coordenador nacional da entidade afirmou que a presidente não poderia se tornar refém de setores conservadores do Congresso Nacional, muitos deles membros da FPE e integrantes da coalizão de apoio ao governo no legislativo. $\mathrm{O}$ coordenador clamou pelo compromisso da presidente com a luta pela promoção dos direitos humanos para que a mesma revogasse a decisão de suspender a distribuição do material, afirmando que "[...] não basta combater a 
pobreza se junto não erradicarmos a violência do preconceito e da discriminação que está ao seu redor" (Rodrigues, 2011: 1).

Os episódios narrados até aqui demonstram que o duplo desafio experimentado por ativistas homossexuais vinculados a partidos políticos (principalmente por aqueles filiados ao PT) desde o surgimento do movimento LGBT no Brasil em alguma medida ainda persiste. Ao compararmos a postura do PT em relação à livre orientação sexual na década de 1980 e atualmente, é bem provável que observaremos maior abertura de parlamentares do PT (assim como também de outros partidos políticos) para as reivindicações do movimento LGBT. Contudo, as conveniências políticas oriundas da necessidade de angariar apoio eleitoral (a exemplo do tempo disponível na Propaganda Eleitoral Gratuita no rádio e na televisão) e de manter uma coalizão de governo integrada por vários opositores dos direitos LGBT acabam por em grande medida neutralizar a maior abertura do PT às reivindicações do movimento LGBT.

\section{Movimento LGBT e partidos políticos: uma radiografia do cenário atual}

O sucinto histórico apresentado anteriormente aponta os diversos desafios enfrentados por ativistas LGBT para incorporar a temática dos direitos sexuais no âmbito partidário brasileiro, principalmente no campo da esquerda. Da mesma forma, viu-se como a questão da vinculação do movimento LGBT a partidos políticos foi (e em grande medida ainda é) um tema sensível no âmbito da militância, pautando muitos dos conflitos internos ao ativismo homossexual. Nesta parte do texto, buscar-se-á refletir sobre como a temática LGBT tem sido incorporada pelos partidos políticos brasileiros na última década. Os dados que serão apresentados são preliminares e fazem parte de um esforço mais amplo de compreender as intrincadas relações entre movimento LGBT e a política institucional no Brasil contemporâneo.

Uma forma de explorar como os partidos políticos brasileiros têm incluído as demandas LGBT em suas pautas políticas foi buscar quais deles possuem setoriais ou grupos LGBT vinculados a sua estrutura partidária. O primeiro partido brasileiro a criar um setorial de Gays e Lésbicas formalmente vinculado à estrutura partidária, como visto anteriormente, foi o PT. Depois de vários debates e resistência por parte da militância partidária, o setorial foi criado em 1992 em São Paulo e estava vinculado ao Diretório Estadual do partido. Em seu trabalho sobre o grupo CORSA, Facchini (2005) menciona o NGLPT como um importante ator nas mobilizações do movimento LGBT paulista na década de 1990. Em minha dissertação de mestrado (Santos, 2006) apontei também para o impacto negativo que a recusa de apoio do NGLPT teve na primeira candidatura abertamente homossexual à Câmara dos Vereadores, o que demonstra a relevância desse ator político nas mobilizações homossexuais em São Paulo. Posteriormente à criação do NGLPT em São Paulo, observou-se o surgimento de outros setoriais nos estados brasileiros. Segundo dados coletados na internet (História Vermelha, 2012), em 
encontro promovido pelo Setorial Nacional do partido em julho de 2012, havia setoriais LGBT petistas organizados em 18 estados brasileiros ${ }^{10}$. O Setorial Nacional LGBT foi criado em 2010 e encontra-se vinculado à Secretaria de Movimentos Populares, que é o órgão do Diretório Nacional do PT responsável por promover a articulação do partido com os movimentos sociais. Além de promover a articulação das demandas dos setoriais estaduais, o Setorial Nacional LGBT tem atuado no sentido de promover as demandas LGBT junto a parlamentares petistas e às instâncias governamentais. O setorial tem sido crítico em relação às alianças entre o PT e partidos conservadores que, para viabilizar a governabilidade, acabam por comprometer as demandas LGBT, a exemplo do recente caso de suspensão da distribuição do "kit anti-homofobia", descrito anteriormente.

Outro importante setorial LGBT vinculado à estrutura partidária é o do Partido Socialista dos Trabalhadores Unidos (PSTU). Criado no mesmo ano de fundação do partido em 1994, a Secretaria Nacional de Gays e Lésbicas é herdeira da Facção Homossexual da Convergência Socialista (Menezes, 2002), que, como visto na parte anterior, teve papel relevante na primeira onda do MHB. A secretaria sempre esteve presente nas mobilizações do movimento LGBT. No caso específico de São Paulo, durante meu período de pesquisa de campo (2004-2006), identifiquei a presença de militantes homossexuais vinculados ao grupo em diversas reuniões do movimento. Além disso, suas bandeiras sempre estiveram visíveis desde a primeira Parada do Orgulho LGBT realizada em São Paulo em 1997. A Secretaria Nacional de Gays e Lésbicas está vinculada à estrutura nacional do partido e não foram identificados setoriais estaduais organizados.

Durante a década de 1990 e os primeiros anos do novo século, PT e PSTU foram os únicos partidos brasileiros a contar com setoriais LGBT. Após 2006, observa-se o surgimento de setoriais LGBT em diversos partidos políticos brasileiros. A proliferação de setoriais LGBT em instâncias partidárias pode ser creditada a uma maior institucionalização da causa LGBT no Brasil, demonstrada pelo maior foco do ativismo em estabelecer organizações formais voltadas a demandas por direitos civis no campo político institucional. Simões e Facchini (2009) identificam que esse processo de institucionalização se inicia ainda na década de 1980, quando da emergência da "segunda onda" do MHB. A mudança na concentração da militância homossexual do eixo Rio de Janeiro-São Paulo para o eixo Rio de Janeiro-Nordeste foi acompanhada de uma postura menos refratária à institucionalidade política. Grupos de militância homossexual como o Grupo Gay da Bahia (GGB) e o Triângulo Rosa-RJ estiveram ativamente engajados nas ações de advocacy junto às instâncias estatais. Data de 1982 um panfleto elaborado pelo GGB no qual o grupo aponta as principais demandas do movimento homossexual e exige de outros partidos políticos, além do PT, que abracem a causa homossexual e

\footnotetext{
${ }^{10}$ Os estados que possuem setoriais LGBT organizados são: Bahia, Alagoas, Amapá, Amazonas, Bahia, Ceará, Distrito Federal, Goiás, Maranhão, Mato Grosso, Minas Gerais, Pará, Paraíba, Pernambuco, Rio de Janeiro, Rio Grande do Sul, Santa Catarina, São Paulo e Tocantins.
} 
criem leis e regulamento que defendam seus direitos (Grupo Gay da Bahia, $1982^{11}$ ). O líder do Triângulo Rosa, João Antonio Mascarenhas, participou ativamente da proposta de inclusão do termo "orientação sexual" como uma das causas de não discriminação na Constituição brasileira (Câmara, 2002). No entanto, é após a eleição de Luiz Inácio Lula da Silva (2003-2011) para a presidência que esse processo de institucionalização se intensifica. Em 2003 é criada a Frente Parlamentar Mista pela Livre Expressão Sexual, englobando deputados e senadores comprometidos com os direitos LGBT (Santos, 2006). Posteriormente, é lançado o Plano "Brasil sem Homofobia”, conjunto de ações de vários ministérios para a promoção dos direitos LGBT, elaborado em parceria com grupos do movimento LGBT brasileiro.

Dentre os partidos que criaram setoriais LGBT recentemente temos o Partido Socialista Brasileiro (PSB). Segundo informações presentes no documento "Caderno de orientações políticos do segmento LGBT socialista" (Partido Socialista Brasileiro, 2012), a primeira iniciativa de constituir um setorial LGBT no partido surgiu de militantes lésbicas da cidade de Macapá (AP). Posteriormente, militantes LGBT de João Pessoa também organizaram um núcleo LGBT no diretório municipal, vindo a criar o primeiro setorial LGBT formalmente vinculado à estrutura partidária em 2007. A Secretaria Municipal da Diversidade pessoense inicia, então, a articulação de militantes LGBT do PSB em outros estados. Em maio de 2011, é realizada a primeira reunião de militantes LGBT do PSB, na sede do Diretório Nacional. Em dezembro do mesmo ano, é eleita a Executiva Nacional LGBT, formalizando a criação de um grupo LGBT vinculado à estrutura nacional do partido. Segundo o mesmo documento, existem núcleos LGBT organizados nos seguintes estados: Alagoas, Amapá, Bahia, Ceará, Espírito Santo, Mato Grosso do Sul, Pará, Paraíba, Pernambuco, Rio Grande do Norte e Rio Grande do Sul.

Ainda no campo da chamada esquerda partidária, temos o Partido do Socialismo e Liberdade (PSOL). Criado em 2005 por iniciativa de ex-parlamentares do PT expulsos por votarem contrariamente à reforma da Previdência e por outros descontentes com os posicionamentos do partido quando no governo federal (Partido Socialismo e Liberdade, 2014), o PSOL tem se posicionado a favor das demandas LGBT. Nas eleições gerais de 2010, o partido surpreendeu o eleitorado paulista com a apresentação de um beijo entre dois rapazes em seu horário eleitoral, explicitamente vinculando o PSOL às demandas LGBT. Em 2011, foi criado o setorial LGBT vinculado ao diretório paulista do partido (UOL, 2011). Em pesquisas na internet, foram identificados mais dois setoriais LGBT estaduais (Amapá ${ }^{12}$ e Rio de Janeiro ${ }^{13}$ ). Embora ainda não possua um setorial LGBT formalmente vinculado à estrutura partidária, o Partido Comunista do Brasil (PCdoB) tem se aberto para a discussão dos direitos sexuais, tendo criado um coletivo LGBT no partido em 2011 (Portal Vermelho, 2011). E mais recentemente (outubro de 2013), foi formado

\footnotetext{
${ }^{11}$ Disponível no Arquivo Edgard Leuenroth, Unicamp.

${ }^{12}$ Vide Alexandro Colares (2011).

${ }^{13}$ Vide Sindicato dos Trabalhadores da Saúde, Trabalho e Previdencia Social do Estado do Rio de Janeiro (2011).
} 
o setorial LGBT do Partido Verde, chamado PV Diversidade e vinculado ao seu diretório do estado de São Paulo.

Até aqui foram apresentados setoriais LGBT criados em partidos políticos identificados na literatura especializada como de esquerda (Kinzo, 1993; Figueiredo; Limongi, 1999; Rodrigues, 2002) ${ }^{14}$. Há, contudo, uma grande "novidade" em relação à inclusão da questão da diversidade sexual no âmbito partidário brasileiro: a criação de setoriais LGBT em partidos comumente identificados na literatura especializada como de "centro" e de "direita" no espectro ideológico. O primeiro desses partidos a contar com um setorial LGBT foi o Partido da Social Democracia Brasileira (PSDB). Embora já existissem desde 1994 grupos LGBT atuantes nas campanhas eleitorais do partido, o grupo Diversidade Tucana (DT) só foi criado oficialmente em 2006. De acordo com seu presidente, Marcos Fernandes, o DT é uma tentativa de tornar mais orgânica a organização de LGBT dentro do PSDB (Blog William De Lucca, 2012). O mesmo rejeita os rótulos de "conservador" e de "direita" muitas vezes atrelados ao PSDB, apontando o compromisso histórico do partido com a causa LGBT. Ele aponta, por exemplo, a inclusão da questão LGBT no Plano Nacional de Direitos Humanos ainda no governo Fernando Henrique Cardoso (1995-2003) e a criação, pelo então prefeito de São Paulo, José Serra (2005-2006), do primeiro órgão de governo específico para tratar da questão da diversidade sexual. Ainda de acordo com o presidente do DT, o grupo foca suas ações na conscientização das bancadas do PSDB na Câmara, no Senado e nas assembleias estaduais a respeito da importância de defender a diversidade sexual. Em várias passagens de sua fala, acusa a presidente Dilma Rousseff de estar refém dos parlamentares da bancada evangélica e afirma que, quando governador do estado de São Paulo (2006-2010), José Serra teria barrado a iniciativa de um deputado estadual aliado do governo e vinculado à bancada evangélica estadual de revogar a lei anti-homofobia do estado ${ }^{15}$. O DT encontra-se vinculado ao diretório paulista do PSDB. A partir de pesquisas na internet, foram identificados dois outros DT nos estados do Pará e Piauí (Partido da Social Democracia Brasileira, 2012).

Também vinculado ao diretório estadual paulista está o grupo Diversidade PTB (Partido Trabalhista Brasileiro). De acordo com material disponibilizado pelo grupo em seu blog (Diversidade PTB, 2010), o Diversidade PTB foi criado em maio de 2010 por iniciativa do deputado federal Campos Machado. Em cerimônia realizada em uma conhecida casa noturna gay de São Paulo, o Diversidade PTB tem como seu presidente de honra Léo Áquila, famosa drag queen paulistana, que se candidatou aos cargos de deputado estadual em 2006 e de vereador em 2008 pelo Partido da República (PR) e a deputado estadual nas eleições de 2014 pelo Partido Social Liberal (PSL). Segundo o mesmo blog, o objetivo principal do grupo é "[...] trabalhar em prol de uma sociedade mais justa, uma sociedade

\footnotetext{
${ }^{14} \mathrm{Na}$ próxima parte do texto, apresento os critérios utilizados para a identificação ideológica dos partidos políticos brasileiros.
}

${ }^{15}$ Lei estadual n. 10.948/2001. 
que respeite a liberdade de cada um, para acabar de uma vez por todas com a discriminação existente" (Diversidade PTB, 2010). Não foi possível identificar as principais ações do grupo, assim como a existência de "Diversidade PTB" em outros diretórios estaduais.

Por fim, identificou-se a existência do grupo "Movimento Diversidade PMDB". Criado em 2009, o grupo está vinculado ao diretório estadual do Partido do Movimento Democrático Brasileiro (PMDB) no Rio Grande do Sul. Segundo seu estatuto, entre os objetivos do grupo estão: a) conscientização de LGBT da importância da política partidária; b) luta por maior participação do Movimento Diversidade PMDB em outros diretórios estaduais; e c) incentivo a que militantes LGBT do partido lancem candidaturas em todos os níveis de governo ${ }^{16}$. Não se identificaram quais são as principais formas de atuação do grupo, assim como não se encontrou "Movimento Diversidade PMDB" organizado em outros estados da federação.

Essa radiografia dos grupos LGBT organizados dentro das estruturas partidárias brasileiras aponta para a crescente importância que os direitos LGBT têm ganhado na política institucional nos últimos anos. Se nas décadas de 1980 e 1990 havia certo "monopólio" da representação política de LGBT por partidos identificados como de esquerda, observa-se a pluralização dessa representação, com grupos LGBT se organizando em partidos de posicionamentos políticos mais ao centro e à direita do espectro ideológico. Mesmo no campo da esquerda, nota-se maior pluralização da representação, com outros partidos, além dos tradicionais apoiadores da causa LGBT (PT e PSTU), criando setoriais LGBT vinculados às suas estruturas partidárias.

A despeito das diferenças existentes nos posicionamentos políticos dos partidos apresentados aqui, observa-se um elemento comum no que tange à inclusão da temática LGBT na estrutura partidária: o surgimento inicial de grupos e setoriais LGBT vinculados às estruturas municipais e estaduais dos partidos políticos. É interessante notar que a questão LGBT tende a ser incluída primeiramente no âmbito dos diretórios estaduais e municipais e apenas em um segundo momento passa a ser contemplada pela estrutura nacional dos partidos. Isso demonstraria certa capilaridade da temática LGBT, que surge nos âmbitos locais e progressivamente vai sendo absorvida pelas estruturas nacionais dos partidos. A única exceção a esse padrão é o PSTU, que já contava com um setorial de lésbicas e gays no seu diretório nacional quando da fundação do partido em 1994.

Outro interessante dado diz respeito à identidade dos grupos LGBT vinculados aos partidos políticos. Os setoriais LGBT dos partidos comumente identificados como de esquerda tendem a adotar as denominações "lésbicas e gays" ou "LGBT" em seus respectivos nomes, à exceção do PV-SP (que denomina seu setorial de PV Diversidade), enquanto que os grupos LGBT de partidos de centro ou de direita tendem a adotar a denominação "diversidade" em seus nomes (a exemplo dos

\footnotetext{
${ }^{16}$ Artigo 3, Estatuto do Movimento Diversidade PMDB/RS (Partido do Movimento Democrático do Brasil, 2013).
} 
setoriais LGBT do PSDB, PTB e PMDB). Uma possível razão para isso seria a que os militantes LGBT dos partidos de centro e de direita enfatizariam a questão da importância de respeitar a diversidade humana (e não apenas de orientação sexual/identidade de gênero), de maneira a evitar possíveis reações contrárias dentro de seus partidos. Afirmar claramente as identidades que constituem o movimento LGBT pode ser identificado por membros mais conservadores desses partidos como suposto "proselitismo" da homossexualidade ${ }^{17}$.

Outra possível razão seria a menor vinculação dos militantes LGBT dos partidos de centro e de direita ao movimento LGBT. Nos materiais disponibilizados pelos grupos "Diversidade" do PSDB, PTB e PMDB, não se identificaram atividades de seus respectivos membros junto ao movimento LGBT de seus estados ou ao movimento LGBT nacional. No caso dos presidentes de dois destes grupos (PSDB e PTB), há indícios, no material pesquisado na internet, de que suas carreiras políticas foram construídas fora do movimento LGBT, o que diferenciaria esses grupos dos setoriais LGBT dos partidos políticos de esquerda, nos quais existe maior vinculação com o movimento social. Esse parece ser também o caso do PV. Embora seja um partido comumente identificado pela literatura acadêmica como de "esquerda", o PV Diversidade tem como coordenador André "Pomba" Cagni, conhecido DJ e empresário da noite paulistana, que possui uma trajetória de vinculação com a temática da diversidade sexual não diretamente vinculada ao ativismo no movimento LGBT local ou nacional. $\mathrm{O}$ mesmo foi candidato a deputado federal pelo partido em 2014.

\section{Demandas LGBT e partidos políticos no Legislativo brasileiro}

Os partidos políticos são considerados pela literatura acadêmica especializada (Duverger, 1980; Sartori, 1982; Downs, 1999) como atores privilegiados de canalização das diferentes demandas existentes na sociedade civil para o Estado nas democracias representativas. Eles seriam responsáveis por diversas funções em um sistema político democrático: a) recrutamento e seleção das elites governantes; b) elaboração de programas de governo e políticas públicas; c) agregação das demandas e interesses existentes na sociedade; d) coordenação e controle dos órgãos governamentais; e e) mobilização política dos indivíduos (Seiler, 2000).

Os partidos seriam, nessa óptica, os atores políticos principais na mediação entre a sociedade civil e o Estado. No caso específico brasileiro, vários cientistas políticos e sociólogos se engajaram em um intenso e produtivo debate sobre o papel desempenhado pelos partidos políticos no sistema político brasileiro. Enquanto alguns deles (Kinzo, 1993; Mainwaring, 1999) apontavam o fraco enraizamento dos partidos políticos na sociedade, o extremo personalismos dos políticos brasileiros

${ }^{17}$ É bom lembrar que a grande maioria dos opositores dos direitos sexuais acusa o movimento LGBT de defender a aprovação de leis e regulamentos que supostamente promoveriam o "homossexualismo". Este argumento foi reiteradamente utilizado por parlamentares contrários à aprovação do PL 122/2006, que criminalizava a discriminação por orientação sexual e identidade de gênero. 
e a quase indistinção ideológica entre os mesmos, outros autores (Figueiredo; Limongi, 1999) defendem a relevância dos partidos políticos na garantia da governabilidade, indicando para uma coerência ideológica em sua atuação parlamentar. Mais recentemente, outros autores tentaram compatibilizar as duas perspectivas, apontando para a relativa "força" dos partidos políticos brasileiros na arena legislativa e sua relativa "fraqueza" na arena eleitoral (Pereira; Mueller, 2003), enquanto que outros (Carreirão, 2006) demonstram certa coerência ideológica dos partidos políticos não apenas no legislativo, mas também no cenário eleitoral.

Até aqui se analisou como se deu a absorção da temática da livre orientação sexual/identidade de gênero nos partidos políticos brasileiros, vistos prioritariamente como organizações que promovem a articulação de interesses e a mobilização política dos indivíduos. Nesta parte do texto, analisar-se-á como os partidos políticos brasileiros têm se posicionado em relação às demandas do movimento LGBT nas últimas três décadas no Legislativo nacional brasileiro (Câmara dos Deputados e Senado Federal). Para tanto, serão analisadas três formas de engajamento dos partidos políticos na promoção dos direitos sexuais de LGBT. São elas: a) proposição de projetos de lei que beneficiam a população LGBT; b) adesão à Frente Parlamentar pela Cidadania GLBT; e c) votação favorável a projetos de lei que reconheçam e garantam direitos à população LGBT.

Antes de analisar os posicionamentos dos partidos políticos em relação à promoção dos direitos de LGBT, é importante definir como classificar os partidos políticos do ponto de vista ideológico. Essa é uma tarefa árdua para sociólogos e cientistas políticos brasileiros, em virtude do relativamente alto número de partidos políticos e da consequente heterogeneidade de posicionamentos no espectro esquerda-direita. Para tanto, farei uso da classificação adotada por Yan Carreirão (2006) em sua análise dos padrões de coligações partidárias no estado de Santa Catarina. O autor resgatou a classificação da ideologia dos partidos políticos consagrada na literatura especializada (a exemplo de Kinzo, 1993; Figueiredo; Limongi, 1999; Rodrigues, 2002), definindo os partidos brasileiros como de "direita", "centro", "esquerda" e "ideologicamente indefinidos". Essa última categoria inclui aqueles partidos que, por insuficiência de informações, não puderam ser identificados como de esquerda, centro ou direita. A classificação ideológica dos partidos políticos levou em conta não só os programas partidários, mas também as declarações de suas lideranças e o posicionamento, nas votações parlamentares, daqueles membros detentores de mandatos públicos (Carreirão, 2006) ${ }^{18}$.

É importante lembrar que os partidos políticos brasileiros sofreram diversas alterações, a exemplo da fusão e criação de novas siglas, desde a publicação do

\footnotetext{
${ }^{18}$ A classificação ideológica dos partidos políticos brasileiros consagrada na literatura leva em conta o posicionamento dos partidos apenas no âmbito nacional, o que acaba por não abarcar as nuances ideológico-programáticas existentes entre os diferentes partidos políticos no âmbito estadual. Um exemplo dessas diferenças, no que diz respeito aos direitos LGBT, pode ser observado no Partido da Social Democracia Brasileira (PSDB). Enquanto os tucanos paulistas têm se posicionado em várias circunstâncias favoráveis às demandas da população LGBT, no estado de Goiás observa-se o protagonismo do deputado João Campos, pastor da Igreja Assembleia de Deus, contrário aos direitos LGBT.
} 
texto acima citado. Foram necessários alguns ajustes, para que o Quadro 1 refletisse o posicionamento dos partidos políticos existentes e com registro aprovado junto ao Tribunal Superior Eleitoral (TSE) na data de 31 de dezembro de 2014. Nos casos de alteração do nome da legenda ou da fusão de partidos políticos, manteve-se a classificação ideológica da sigla original ${ }^{19}$. Incluiu-se o Partido do Socialismo e Liberdade (PSOL) como de "esquerda", dado que o mesmo, criado em 2005, constitui uma dissidência do PT e tem se identificado claramente com as bandeiras da esquerda brasileira (incluindo a defesa dos direitos LGBT). Nos casos de partidos recém-criados, como o Partido Social Democrático (PSD), o Partido Pátria Livre (PPL), o Partido Ecológico Nacional (PEN), o Partido Republicano da Ordem Social (PROS) e o Solidariedade (SD), optou-se por classificá-los como "ideologicamente indefinidos" (Quadro 1).

No caso das proposições de leis e regulamentos que garantam direitos à população LGBT, farei uso de dados levantados por Rosa Oliveira (2012) na Câmara dos Deputados e no Senado Federal no período de 1995 a 2011. Foram identificadas pela autora 97 proposições legislativas, sendo 84 delas oriundas da Câmara dos Deputados e 13 do Senado Federal. Muitas dessas proposições contaram com a assinatura de mais de um parlamentar de diferentes partidos políticos. O partido que mais assinou projetos de lei favoráveis ao segmento LGBT foi o PT, com 38 assinaturas ao todo, seguido do PMDB com 10 assinaturas, PV com 9 assinaturas, PDT com 7 assinaturas e PSDB com 6 assinaturas (Oliveira, 2012: 60). Ao todo, foram 19 os partidos políticos que apoiaram a causa LGBT no Congresso Nacional ${ }^{20}$.

Se agregarmos os partidos políticos de acordo com seu posicionamento no espectro ideológico, observa-se que a maioria das assinaturas (66, ou 60,55\% do total) é oriunda de partidos de esquerda (Tabela 1). No entanto, não se pode desconsiderar que parte relevante das assinaturas é oriunda de partidos identificados na literatura acadêmica como de direita (22, ou 20,18\%), seguida das assinaturas oriundas de partidos de centro (16, ou 14,68\%) e ideologicamente indefinidos (5, ou 4,59\% do total). Os dados demonstram que embora haja representação majoritária dos partidos de esquerda quando da proposição de leis pró-LGBT, não se pode afirmar que essa temática seja "exclusiva" da esquerda partidária no Congresso Nacional brasileiro. Da mesma forma, o PT, embora ocupe posição de destaque na assinatura de projetos de lei pró-LGBT no campo da esquerda partidária, compartilha com outras siglas a preocupação com o respeito da

\footnotetext{
${ }^{19}$ Em estudo sobre as migrações partidárias entre os parlamentares brasileiros, Marenco dos Santos (2001) identificou que as mudanças de partidos não ocorrem de maneira aleatória. Os parlamentares tendem a trocar de legenda dentro do mesmo espectro ideológico, o que reforçaria a hipótese da consistência ideológica das lealdades partidárias. Sendo assim, é razoável supor que as siglas que mudaram de nome tendem a manter seus antigos posicionamentos ideológico-programáticos.

${ }^{20}$ Em seu levantamento, a autora não levou em conta as alterações ocorridas nas legendas partidárias no período analisado, considerando, por exemplo, o Partido da Frente Liberal (PFL) e o Democratas (DEM) como se fossem dois partidos distintos, esquecendo que o PFL mudou seu nome para DEM em 2007. O mesmo ocorreu no caso do Partido Progressista Brasileiro (PPB) que passou a se chamar Partido Progressista (PP) em 2003.
} 
Quadro 1 - Classificação dos partidos políticos a partir de sua posição no espectro ideológico (1986-2012).

\begin{tabular}{|c|c|c|c|}
\hline Esquerda & Centro & Direita & $\begin{array}{c}\text { Ideologicamente } \\
\text { indefinidos }\end{array}$ \\
\hline & & PP (PPB; PPR; & \\
& & PDS); DEM (PFL); & PST; PHS; PTC; \\
PT; PDT; PPS; PCdoB; & & PTC (PRN); PTB & PTdoB; PRTB; PTN; \\
PSB; PV; PSTU; PCO; & PMDB; PSDB & (PAN, PSD-198722); & PSD-2011; PPL; PEN; \\
PMN; PSOL; PCB & & PSDC (PDC); PSC; & PROS; SD \\
& & PSP; PRP; PSL; PR & \\
& & (PL,PRONA); PRB & \\
\hline
\end{tabular}

Fontes: Figueiredo e Limongi (1999); Carreirão (2006)

diversidade de orientação sexual e identidade de gênero. Isso aponta para a não congruência entre as clivagens ideológico-partidárias e a promoção dos direitos LGBT. Voltarei a esse ponto adiante.

Outra forma de medir o comprometimento dos partidos políticos com a defesa dos direitos sexuais é analisar as adesões de parlamentares a frentes parlamentares pró-direitos LGBT. As frentes parlamentares são grupos de parlamentares (deputados e/ou senadores) de caráter suprapartidário que se organizam em torno de temáticas de interesse comum. Segundo Coradini (2010), as frentes parlamentares são grupos que promovem a articulação de interesses, constituindo-se enquanto "espaços" de "opinião mobilizada" dentro do Parlamento. Além de agregar deputados e senadores com posicionamentos semelhantes em uma dada temática, as frentes parlamentares auxiliam nos processos de definição e organização de interesses, que ocorrem em interação tanto com a chamada "sociedade civil organizada" quanto os membros do poder Executivo. Segundo dados obtidos no sítio da Câmara dos Deputados, foram criadas na 54 Legislatura (2011-2015) 163 frentes parlamentares. No caso específico da questão LGBT, a organização da primeira frente parlamentar ocorreu em outubro de 2003. Nomeada de "Frente Parlamentar Mista pela Livre Expressão Sexual", a frente contava com a participação de deputados e senadores defensores dos direitos LGBT. O grupo promoveu diversos encontros e palestras sobre direitos sexuais. Os dados disponíveis apontam que a Frente contou com a assinatura de 89 parlamentares, sendo 80 (92,6\%) deputados e 9 senadores $(7,4 \%)$. Mais da metade dos parlamentares da Frente pela Livre Expressão Sexual era de petistas (47, ou 56\% do total), seguida do PCdoB (com 5 parlamentares, ou 6\% do total), do PDT e do PPS (ambos com 4 parlamentares, ou 4,8\% do total) (Tabela 2).

Em 2007, com a eleição da 53a Legislatura (2007-2011), a Frente foi renomeada para "Frente Parlamentar para a Cidadania GLBT". Atualmente, vários parlamentares têm atuado no sentido de reorganizar a Frente Parlamentar pró-LGBT, sendo que

${ }^{21}$ Utilizo a sigla PSD-1987 para diferenciar o Partido Social Democrático fundado em 1987 e incorporado ao PTB em 2006 do partido de mesmo nome fundado pelo ex-prefeito de São Paulo, Gilberto Kassab, em 2011 (identificado como PSD-2011). 
Tabela 1 - Assinaturas de projetos de lei pró-LGBT (1995-2011).

\begin{tabular}{|l|c|c|}
\hline \multicolumn{1}{|c|}{ Partidos de esquerda } & & \\
\hline PT & 38 & $34,86 \%$ \\
\hline PV & 9 & $8,26 \%$ \\
\hline PDT & 7 & $6,42 \%$ \\
\hline PSB & 6 & $5,50 \%$ \\
\hline PCdoB & 2 & $1,83 \%$ \\
\hline PPS & 2 & $1,83 \%$ \\
\hline PSOL & 2 & $1,83 \%$ \\
\hline & & $\mathbf{6 0 , 5 5 \%}$ \\
\hline & & $9,17 \%$ \\
\hline PMDB Partidos de direita centro & 10 & $5,50 \%$ \\
\hline PSDB & 6 & $\mathbf{1 4 , 6 8 \%}$ \\
\hline & & $5,50 \%$ \\
\hline & & $4,59 \%$ \\
\hline DEM/PFL & 6 & $2,75 \%$ \\
\hline PSC & 5 & $1,83 \%$ \\
\hline PP/PPB & 3 & $2,75 \%$ \\
\hline PR & 2 & $1,83 \%$ \\
\hline PTB & 3 & $0,92 \%$ \\
\hline PRB & 2 & $\mathbf{2 0 , 1 8 \%}$ \\
\hline PRONA & 1 & $\mathbf{1 0 0 , 0 0 \%}$ \\
\hline & & $1,83 \%$ \\
\hline Partidos ideologicamente indefinidos & & $1,83 \%$ \\
\hline PST & 2 & $0,92 \%$ \\
\hline PTC & 1 & \\
\hline PHS & & \\
\hline & & \\
\hline & & \\
\hline
\end{tabular}

Fonte: Oliveira (2012)

Tabela 2 - Filiação partidária Membros da Frente Parlamentar pela Livre Expressão Sexual (2003-2007) (INOVA, 2005).

\begin{tabular}{|c|c|c|c|}
\hline & Frequência & (\%) do total & Percentual válido \\
\hline PT & 47 & 56,0 & 56,0 \\
\hline PC do B & 5 & 6,0 & 6,0 \\
\hline DEM/PFL & 3 & 3,6 & 3,6 \\
\hline PDT & 4 & 4,8 & 4,8 \\
\hline PP & 2 & 2,4 & 2,4 \\
\hline PSB & 3 & 3,6 & 3,6 \\
\hline PMDB & 3 & 3,6 & 3,6 \\
\hline PR/PL & 3 & 3,6 & 3,6 \\
\hline PPS & 4 & 4,8 & 4,8 \\
\hline PV & 2 & 2,4 & 2,4 \\
\hline PTB & 3 & 3,6 & 3,6 \\
\hline PSDB & 2 & 2,4 & 2,4 \\
\hline PSOL & 3 & 3,6 & 3,6 \\
\hline Total & 84 & 100,0 & 100,0 \\
\hline
\end{tabular}


até o presente momento (dezembro de 2014) ela ainda não havia sido formalizada ${ }^{22}$. Durante sua vigência, a Frente contou com a assinatura de 215 parlamentares, sendo 199 (92,6\%) deputados e 16 senadores $(7,4 \%)$. No que se refere à filiação partidária dos parlamentares, o PT, como esperado, é o partido com o maior número de membros da Frente Parlamentar pela Cidadania GLBT (74, ou 34,4\% do total). Contudo, nota-se um dado interessante, que reforça a hipótese da não congruência entre clivagens ideológico-partidárias e posicionamento favorável aos direitos LGBT: o partido com o segundo maior contingente de parlamentares é o PMDB com 26 parlamentares (ou 12,1\% do total), comumente identificado como de "centro", sendo seguido em quarto lugar pelo Democratas (DEM, antigo PFL), com 14 parlamentares (ou 6,5\% do total), classificado pela literatura especializada como de "direita" (Tabela 3).

Já quando agregamos os partidos políticos de acordo com suas identidades ideológicas, observa-se que a grande maioria (132, ou 61,4\% do total) dos deputados e senadores da Frente Parlamentar pela Cidadania GLBT pertence a partidos políticos identificados como de "esquerda", sendo seguidos dos deputados de "direita", com 43 parlamentares (ou 20\% do total), e de "centro" com 38 parlamentares (17,7\% do total) e de partidos ideologicamente indefinidos (2, ou $0,9 \%$ do total) (Tabela 4). É interessante notar a equivalência entre esses dados e os referentes a proposições de projetos de lei pró-LGBT. Uma provável razão é que há uma alta probabilidade de que os parlamentares que apresentam projetos de lei que favorecem o segmento LGBT também façam parte da Frente Parlamentar. Contudo, não se pode esquecer que o número de filiados à Frente Parlamentar (215 parlamentares) é quase o dobro do número de assinaturas favoráveis a propostas de legislação em prol dos direitos sexuais (109 assinaturas) (Oliveira, 2012), o que demonstra que vários são os deputados e/ou senadores que se posicionam a favor da causa LGBT, sem que isso implique necessariamente o apoio declarado a projetos de lei para esse segmento da população. Esses dados apontam certa consistência no apoio dos parlamentares brasileiros aos direitos sexuais, que conta com a presença majoritária dos partidos de "esquerda", mas também o apoio expressivo de partidos de "centro" e de "direita".

Agora analisar-se-ão as votações de proposições legislativas que visavam à promoção de direitos da população LGBT no Brasil. Foram pesquisadas todas as iniciativas legislativas que contemplaram esse segmento da população desde 0 retorno dos governos civis (1985) até os dias de hoje (2012). Foram identificadas (quatro) propostas de mudança na legislação que especificamente contemplavam a promoção dos direitos sexuais de LGBT. Foram elas:

1) Proposta de inclusão do termo "orientação sexual" nas razões de não discriminação do artigo $3^{\circ}$ da Constituição Federal (Assembleia Nacional Constituinte, julho de 1987 e janeiro de 1988);

\footnotetext{
${ }^{22}$ As frentes parlamentares duram até o fim da legislatura nas quais foram criadas, sendo necessária sua rearticulação após a investidura dos novos parlamentares.
} 
2) Proposta de inclusão do termo "orientação sexual" nas razões de não discriminação do artigo $3^{\circ}$ da Constituição Federal (Revisão Constitucional, fevereiro de 1994);

3) Projeto de Lei n. 1.151/1995, que reconhece a Parceria Civil Registrada (PCR) entre pessoas do mesmo sexo (Comissão Especial, Câmara dos Deputados, novembro de 1996);

4) Projeto de Lei n. 5.003/2001, que criminaliza a homofobia (Comissão de Constituição e Justiça, Câmara dos Deputados, novembro de 2005).

A proposta de inclusão do termo "orientação sexual" nas razões de não discriminação elencadas na constituição foi objeto de votação nominal na comissão

Tabela 3 - Filiação partidária Membros da Frente Parlamentar Cidadania GLBT (2007-2011).

\begin{tabular}{|c|c|c|c|}
\hline & Frequência & (\%) do total & Percentual válido \\
\hline PT & 74 & 34,4 & 34,4 \\
\hline PC do B & 12 & 5,6 & 5,6 \\
\hline DEM & 14 & 6,5 & 6,5 \\
\hline PDT & 11 & 5,1 & 5,1 \\
\hline PP & 11 & 5,1 & 5,1 \\
\hline PSB & 16 & 7,4 & 7,4 \\
\hline PMDB & 26 & 12,1 & 12,1 \\
\hline PR & 7 & 3,3 & 3,3 \\
\hline PPS & 8 & 3,7 & 3,7 \\
\hline PV & 6 & 2,8 & 2,8 \\
\hline PMN & 1 &, 5 &, 5 \\
\hline PTB & 8 & 3,7 & 3,7 \\
\hline PSDB & 12 & 5,6 & 5,6 \\
\hline PSOL & 4 & 1,9 & 1,9 \\
\hline PHS & 1 &, 5 &, 5 \\
\hline PSC & 3 & 1,4 & 1,4 \\
\hline PTC & 1 &, 5 & 100,0 \\
\hline Total & 215 & 100,0 & \\
\hline
\end{tabular}

Fonte: Associação Brasileira de Lésbicas, Gays, Bissexuais, Travestis e Transexuais (2014)

Tabela 4 - Filiação ideológico-partidária Membros da Frente Parlamentar Cidadania GLBT (2007-2011).

\begin{tabular}{|l|c|c|c|}
\hline & Frequência & (\%) do total & $\begin{array}{c}\text { Percentual } \\
\text { válido }\end{array}$ \\
\hline Esquerda & 132 & 61,4 & 61,4 \\
\hline Centro & 38 & 17,7 & 17,7 \\
\hline Direita & 43 & 20,0 & 20,0 \\
\hline Indefinidos ideologicamente & 2 &, 9 &, 9 \\
\hline Total & 215 & 100,0 & 100,0 \\
\hline
\end{tabular}

Fonte: Projeto Aliadas (Associação Brasileira de Lésbicas, Gays, Bissexuais, Travestis e Transexuais, 2014) 
de sistematização em julho de 1987 e novamente no plenário da Assembleia Nacional Constituinte em $1988^{23}$. A segunda proposta versava sobre o mesmo tema e foi votada no plenário, em sessão conjunta da Câmara e do Senado. No caso da PCR, embora tenha sido aprovado na Comissão Especial, o projeto de lei nunca foi votado pelo plenário. Em duas ocasiões o projeto de lei chegou a ser colocado na pauta de votação, sendo então retirado pelos seus defensores, por receio de sua rejeição pelos parlamentares (Santos, 2011). Já no que se refere ao projeto de lei de criminalização da homofobia, após ter sido aprovado pela Comissão de Constituição e Justiça (CCJ) da Câmara dos Deputados por unanimidade, o mesmo foi encaminhado para votação em plenário em regime de urgência, sendo aprovado por votação simbólica em 2006. Posteriormente, o projeto de lei foi encaminhado para o Senado Federal, onde sofreu intensa oposição de senadores vinculados à FPE. O PLC 122/2006 tramitou no Senado Federal até o ano de 2011, quando foi regimentalmente arquivado ${ }^{24}$.

A proposta de inclusão do termo "orientação sexual" na constituição foi apresentada pelo grupo Triângulo Rosa-RJ, tendo sido seu presidente, João Antônio Mascarenhas, o principal porta-voz do MHB em defesa da medida. Como tem ocorrido em todas as votações de projetos de lei que visam garantir direitos a LGBT, a atuação da bancada evangélica foi decisiva para a rejeição da proposta. Depois de acalorados debates ${ }^{25}$, a proposta foi rejeitada por 60 votos contrários e 32 votos a favor de um total de 92 parlamentares presentes (Tabela 5). Ao cruzarmos os dados de posicionamentos (favorável ou não à proposta) com a filiação partidária do constituinte, observa-se que o principal defensor da proposta foi o PMDB, com 18 votos favoráveis (56,3\% do total de votos favoráveis). Contudo, ao olharmos para os constituintes contrários à proposta, a maioria também é filiada ao PMDB (29 ou 48,3\% do total de votos contrários). Isso é explicável, primeiramente, pelo fato de o PMDB constituir a maior bancada da ANC. Mas também parece indicar que a filiação ideológico-partidária é um fraco indicador do posicionamento dos parlamentares em relação a propostas de legislação pró-LGBT.

Ao agregarmos os partidos políticos de acordo com suas posições ideológicas, nota-se que o centro ideológico continua a ser o principal apoiador da causa homossexual na ANC (20 votos, ou 62,5\% do total de votos favoráveis), sendo seguido pelos partidos de esquerda com 7 votos (21,9\% do total de votos favoráveis) (Tabela 6). Quando olhamos para os opositores dos direitos homossexuais, nota-se também o predomínio dos partidos de centro (29 votos, ou 48,3\% do total de votos contrários), seguido dos partidos de direita com 28 votos ( $46,7 \%$ do total de votos

\footnotetext{
${ }^{23}$ As votações da Assembleia Nacional Constituinte e do Congresso Revisional eram realizadas de forma conjunta por deputados e senadores.

${ }^{24}$ De acordo com o parágrafo $1^{\circ}$ do artigo 332 do Regimento Interno do Senado (Senado Federal, 1970), todos os projetos de lei que tramitaram por mais de duas legislaturas e não foram votados são automaticamente arquivados.

${ }^{25}$ Para uma análise dos debates em torno da proposta na ANC, vide Câmara (2002) e Santos (2011).
} 
Tabela 5 - Comissão de sistematização - ANC (1987).

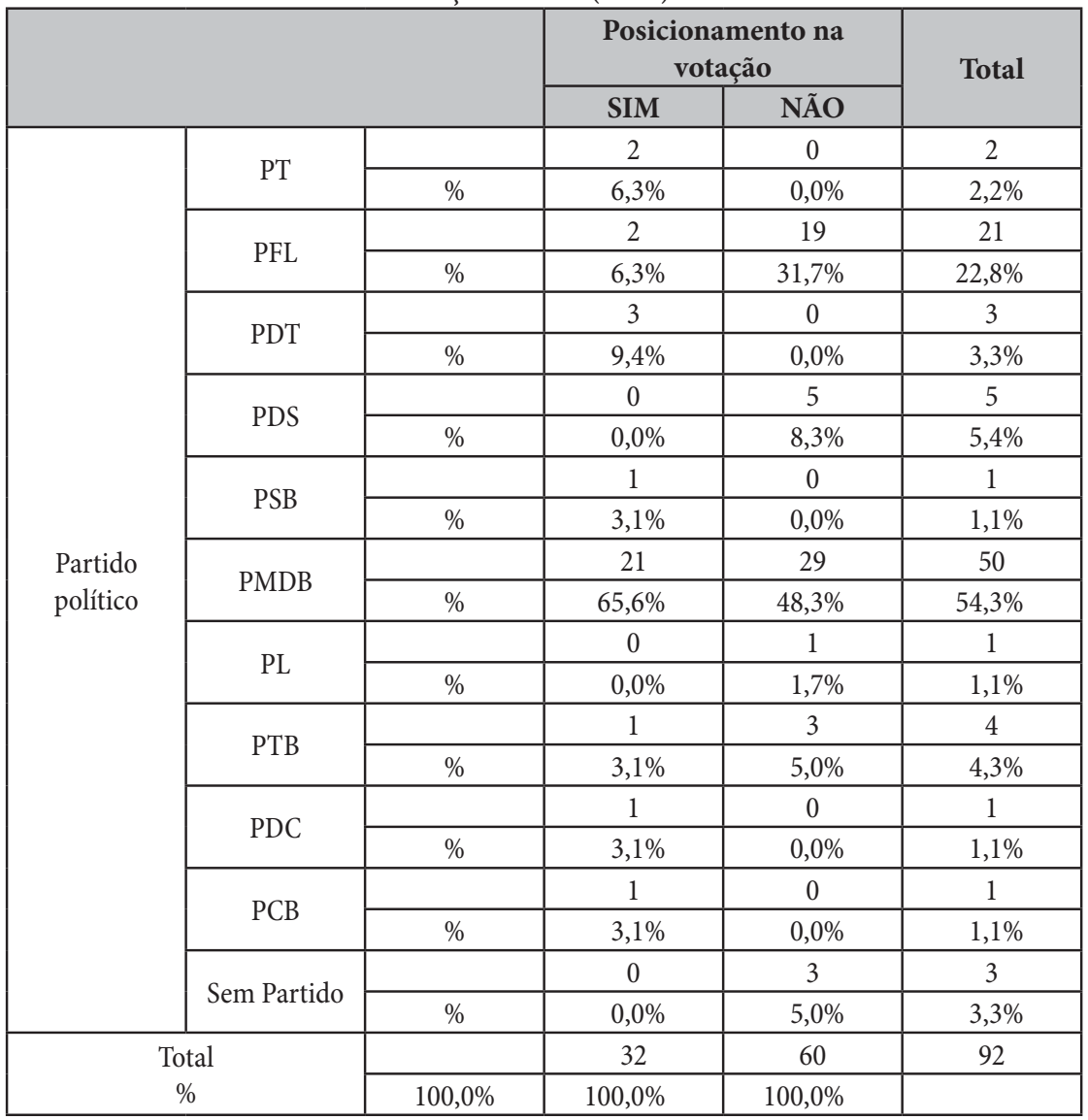

Fonte: Anais da ANC

Tabela 6 - Comissão de sistematização ANC (1987).

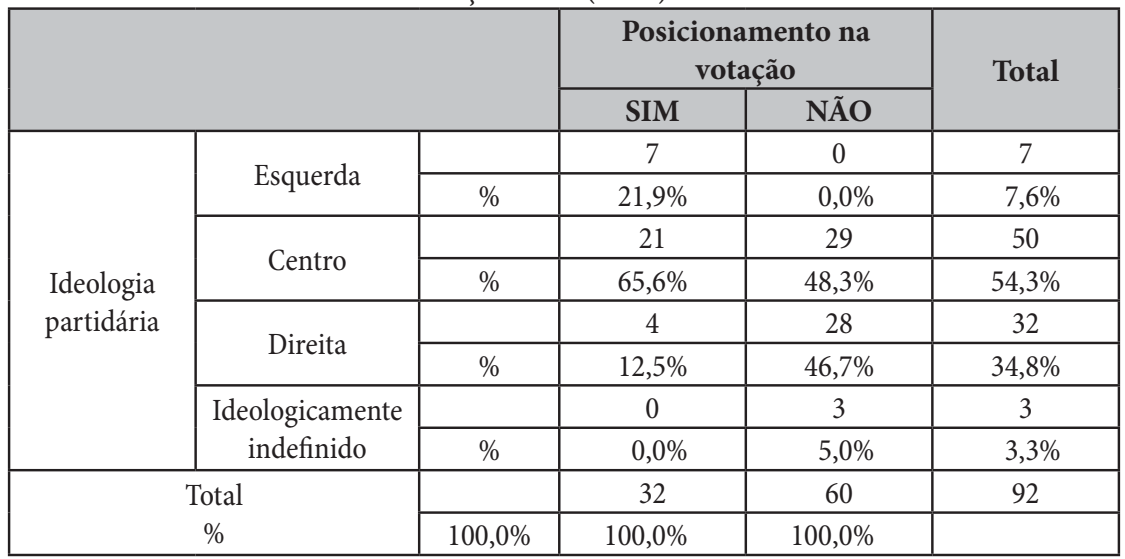

Fonte: Anais da ANC 
contrários). Observou-se também a inexistência de parlamentares de esquerda entre os opositores dos direitos homossexuais.

Embora rejeitada na Comissão de Sistematização, a proposta voltou ao plenário da ANC, por iniciativa do então deputado constituinte José Genoíno (PT/SP), que apresentou destaque em fevereiro de 1988. Mais uma vez a proposta foi rejeitada por 317 votos contrários, 130 favoráveis e 14 abstenções (Tabela 7). Ao comparamos o placar da votação em plenário com a votação da comissão de sistematização, identifica-se o mesmo padrão de posicionamento dos parlamentares em relação aos direitos de LGBT. Dentre os parlamentares favoráveis, a maioria era filiada ao PMDB (70 parlamentares, ou 54,3\% de votos favoráveis ${ }^{26}$ ), assim como a maioria dos parlamentares contrária à proposta (146 parlamentares, ou 47,1\% dos votos contrários).

O padrão também se mantém quando agregamos os partidos de acordo com sua identidade ideológica. Os partidos de "centro" figuram entre os principais defensores ( 73 votos ou 56,6\% dos votos favoráveis) e opositores (148 votos, ou $47,7 \%$ dos votos contrários) dos direitos dos homossexuais (Tabela 8). A diferença é que quando olhamos para os "segundos lugares", nota-se que estes são ocupados pelos partidos de esquerda, quando se trata de votação favorável à proposta de destaque (41 votos ou 31,8\% dos votos favoráveis) e pelos partidos de direita no que se refere aos opositores da proposta (143 votos, ou 46,1\% dos votos contrários).

Quando promulgada em outubro de 1988, a nova constituição brasileira previu, no artigo $3^{\circ}$ do Ato das Disposições Constitucionais Transitórias, a realização, no prazo de cinco anos, de uma revisão constitucional, na qual a constituição poderia ser alterada pela "maioria absoluta dos membros do Congresso Nacional, em sessão unicameral”. Por iniciativa do então deputado federal Fábio Feldman (PSDB/SP), a proposta de inclusão do termo "orientação sexual" nas razões de não discriminação previstas no inciso IV do artigo $3^{\circ}$ da constituição voltou à discussão no plenário do Congresso Nacional, tendo sido novamente rejeitada por 250 votos contrários, 53 favoráveis e 7 abstenções (Tabela 9). Ao analisarmos os votos favoráveis, nota-se que o $\mathrm{PSDB}^{27}$ assume a liderança entre os partidos políticos pró-direitos dos homossexuais, com 19 votos favoráveis $(35,2 \%$ dos votos favoráveis), sendo seguido pelo PFL (9, ou 16,7\% dos votos favoráveis), pelo PMDB e pelo PPR (ambos com 7 votos ou 13\% dos votos favoráveis cada).

Ao agregar os partidos por ideologia, observa-se uma vez o predomínio dos parlamentares dos partidos de centro entre os defensores dos direitos homossexuais, com 26 votos (48,1\% dos votos favoráveis) (Tabela 10). A "surpresa" é o apoio de 21 parlamentares de partidos de direita (38,9\% dos votos favoráveis) à proposta. É importante salientar que essa porcentagem maior de votos de partidos de direita pode estar relacionada à ausência do PT na votação. Na época, o diretório

\footnotetext{
${ }^{26} \mathrm{O}$ total de votos levados em conta nas Tabelas 7 e 8 é de 452, visto que não foi possível identificar a filiação partidária de 9 constituintes.
}

${ }^{27}$ É bom salientar que o PSDB foi fundado a partir de uma dissidência do PMDB. 
Tabela 7 - Plenário ANC (1988).

\begin{tabular}{|c|c|c|c|c|c|c|}
\hline & \multicolumn{3}{|c|}{ Posicionamento na votação } & \multirow{2}{*}{ Total } \\
\hline & & & SIM & NÃO & Abstenção & \\
\hline \multirow{26}{*}{$\begin{array}{l}\text { Partido } \\
\text { político }\end{array}$} & \multirow{2}{*}{ PT } & & 16 & 0 & 0 & 16 \\
\hline & & $\%$ & $12,3 \%$ & $0,0 \%$ & $0,0 \%$ & $3,5 \%$ \\
\hline & \multirow{2}{*}{ PC do B } & & 3 & 0 & 0 & 3 \\
\hline & & $\%$ & $2,3 \%$ & $0,0 \%$ & $0,0 \%$ &, $7 \%$ \\
\hline & \multirow{2}{*}{ PFL } & & 6 & 94 & 3 & 103 \\
\hline & & $\%$ & $4,6 \%$ & $30,1 \%$ & $23,1 \%$ & $22,6 \%$ \\
\hline & \multirow{2}{*}{ PDT } & & 15 & 9 & 0 & 24 \\
\hline & & $\%$ & $11,5 \%$ & $2,9 \%$ & $0,0 \%$ & $5,3 \%$ \\
\hline & \multirow{2}{*}{ PDS } & & 3 & 30 & 2 & 35 \\
\hline & & $\%$ & $2,3 \%$ & $9,6 \%$ & $15,4 \%$ & $7,7 \%$ \\
\hline & \multirow{2}{*}{ PSB } & & 4 & 0 & 0 & 4 \\
\hline & & $\%$ & $3,1 \%$ & $0,0 \%$ & $0,0 \%$ &, $9 \%$ \\
\hline & \multirow{2}{*}{ PMDB } & & 74 & 148 & 7 & 229 \\
\hline & & $\%$ & $56,9 \%$ & $47,4 \%$ & $53,8 \%$ & $50,3 \%$ \\
\hline & \multirow{2}{*}{ PL } & & 0 & 7 & 0 & 7 \\
\hline & & $\%$ & $0,0 \%$ & $2,2 \%$ & $0,0 \%$ & $1,5 \%$ \\
\hline & \multirow{2}{*}{ РTB } & & 1 & 11 & 0 & 12 \\
\hline & & $\%$ & $8 \%$ & $3,5 \%$ & $0,0 \%$ & $2,6 \%$ \\
\hline & \multirow{2}{*}{ PSC } & & 1 & 0 & 0 & 1 \\
\hline & & $\%$ &, $8 \%$ & $0,0 \%$ & $0,0 \%$ &, $2 \%$ \\
\hline & \multirow{2}{*}{ PDC } & & 0 & 4 & 0 & 4 \\
\hline & & $\%$ & $0,0 \%$ & $1,3 \%$ & $0,0 \%$ & ,9\% \\
\hline & \multirow{2}{*}{ PCB } & & 3 & 0 & 0 & 3 \\
\hline & & $\%$ & $2,3 \%$ & $0,0 \%$ & $0,0 \%$ &, $7 \%$ \\
\hline & \multirow{2}{*}{ Sem partido } & & 4 & 9 & 1 & 14 \\
\hline & & $\%$ & $3,1 \%$ & $2,9 \%$ & $7,7 \%$ & $3,1 \%$ \\
\hline \multirow{2}{*}{\multicolumn{2}{|c|}{$\begin{array}{c}\text { Total } \\
\%\end{array}$}} & & 130 & 312 & 13 & 455 \\
\hline & & $100,0 \%$ & $100,0 \%$ & $100,0 \%$ & $100,0 \%$ & \\
\hline
\end{tabular}

Fonte: Anais da ANC

nacional do partido impediu os parlamentares do partido de manifestar seu voto na Revisão Constitucional ${ }^{28}$. Contudo, não se pode negar o peso dos parlamentares de direita entre os apoiadores da proposta. Já entre os opositores, os partidos de direita assumiram a liderança entre os parlamentares contrários à proposta, com 151 votos (60,4\% dos votos contrários), seguidos pelos parlamentares de centro ( 88 votos, ou $35,2 \%$ do total de votos contrários).

As sucessivas derrotas experimentadas pelas propostas de legislação em prol dos direitos de homossexuais no Congresso Nacional não arrefeceram os ativistas LGBT. Em dezembro do ano seguinte (1995), a então deputada Marta Suplicy (PT/SP) apresentou o Projeto de Lei n. 1.151, que visava reconhecer a união civil

${ }^{28}$ Vide João Antônio Mascarenhas (1994). 
Tabela 8 - Plenário ANC (1988).

\begin{tabular}{|c|c|c|c|c|c|c|}
\hline & \multicolumn{3}{|c|}{ Posicionamento na votação } & \multirow{2}{*}{ Total } \\
\hline & & & SIM & NÃO & Abstenção & \\
\hline \multirow{8}{*}{$\begin{array}{l}\text { Ideologia } \\
\text { partidária }\end{array}$} & \multirow{2}{*}{ Esquerda } & & 41 & 9 & 0 & 50 \\
\hline & & $\%$ & $31,5 \%$ & $2,9 \%$ & $0,0 \%$ & $11,0 \%$ \\
\hline & \multirow{2}{*}{ Centro } & & 74 & 148 & 7 & 229 \\
\hline & & $\%$ & $56,9 \%$ & $47,4 \%$ & $53,8 \%$ & $50,3 \%$ \\
\hline & \multirow{2}{*}{ Direita } & & 11 & 146 & 5 & 162 \\
\hline & & $\%$ & $8,5 \%$ & $46,8 \%$ & $38,5 \%$ & $35,6 \%$ \\
\hline & \multirow{2}{*}{$\begin{array}{c}\text { Ideologicamente } \\
\text { indefinido }\end{array}$} & & 4 & 9 & 1 & 14 \\
\hline & & $\%$ & $3,1 \%$ & $2,9 \%$ & $7,7 \%$ & $3,1 \%$ \\
\hline \multirow{2}{*}{\multicolumn{2}{|c|}{$\begin{array}{c}\text { Total } \\
\%\end{array}$}} & & 130 & 312 & 13 & 455 \\
\hline & & $100,0 \%$ & $100,0 \%$ & $100,0 \%$ & $100,0 \%$ & \\
\hline
\end{tabular}

Fonte: Anais da ANC

(posteriormente alterada para Parceria Civil Registrada ${ }^{29}$ ) entre casais do mesmo sexo. Foram realizadas ao longo do ano de 1996 treze reuniões para debater a relevância da matéria e a sua constitucionalidade. Após os debates, o parecer do então deputado Roberto Jefferson (PTB/RJ) foi submetido à votação na Comissão Especial e aprovado por 11 votos favoráveis e 5 contrários. Mesmo com o parecer favorável do relator, o projeto nunca chegou a ser votado no plenário, por receio de ser rejeitado. Na década seguinte à apresentação do PCR, a então deputada Iara Bernardi (PT/SP) apresentou projeto de lei que criminaliza práticas discriminatórias direcionadas a LGBT (PL 5.003/2001) nos mesmos termos da lei que proíbe a discriminação por raça e gênero ${ }^{30}$. O projeto de lei foi discutido pela Comissão de Constituição e Justiça (CCJ) da Câmara dos Deputados em 2005 e aprovado por unanimidade dos presentes (57 parlamentares). Posteriormente o mesmo foi aprovado por votação simbólica no plenário e remetido ao Senado Federal, onde foi discutido nas Comissões de Direitos Humanos e Legislação Participativa e de Assuntos Sociais, mas nunca chegou a ser votado.

É difícil estabelecer comparações entre as votações realizadas no plenário e as ocorridas nas Comissões, já que aquelas contaram com a presença de diversos parlamentares das duas casas (Câmara e Senado), enquanto que estas tiveram um número reduzido de membros da Câmara dos Deputados ${ }^{31}$. Além disso, uma das votações (criminalização da homofobia) foi vencida por unanimidade, faltando assim informações relevantes sobre o perfil dos opositores da proposta ${ }^{32}$. No entanto, se agregarmos os votos dos parlamentares de acordo com a identificação ideológica

\footnotetext{
${ }^{29}$ Para mais detalhes sobre os debates em torno do projeto de parceria civil, vide Mello (2005) e Santos (2011).

${ }^{30}$ Lei federal n. 7.716/1989.

${ }^{31}$ O partido político com a maior bancada na Comissão Especial de votação do PCR em 1996 foi o PPB, com 3 deputados, enquanto que na votação da criminalização da homofobia, em 2005, a maior bancada na CCJ era a do PT com 12 deputados.

${ }^{32}$ De acordo com as notas taquigráficas (Câmara dos Deputados, 2006), o projeto de lei não chegou a ser discutido na comissão, sendo aprovado por votação simbólica.
} 
de seus partidos, observa-se que a partir de 1996 os partidos de "esquerda" assumem a liderança na defesa dos direitos LGBT, com $54,5 \%$ dos votos favoráveis (6 deputados) à PCR (Tabela 11) e 43,9\% dos votos favoráveis (25 deputados) à

Tabela 9 - Revisão Constitucional (Câmara dos Deputados, 1994).

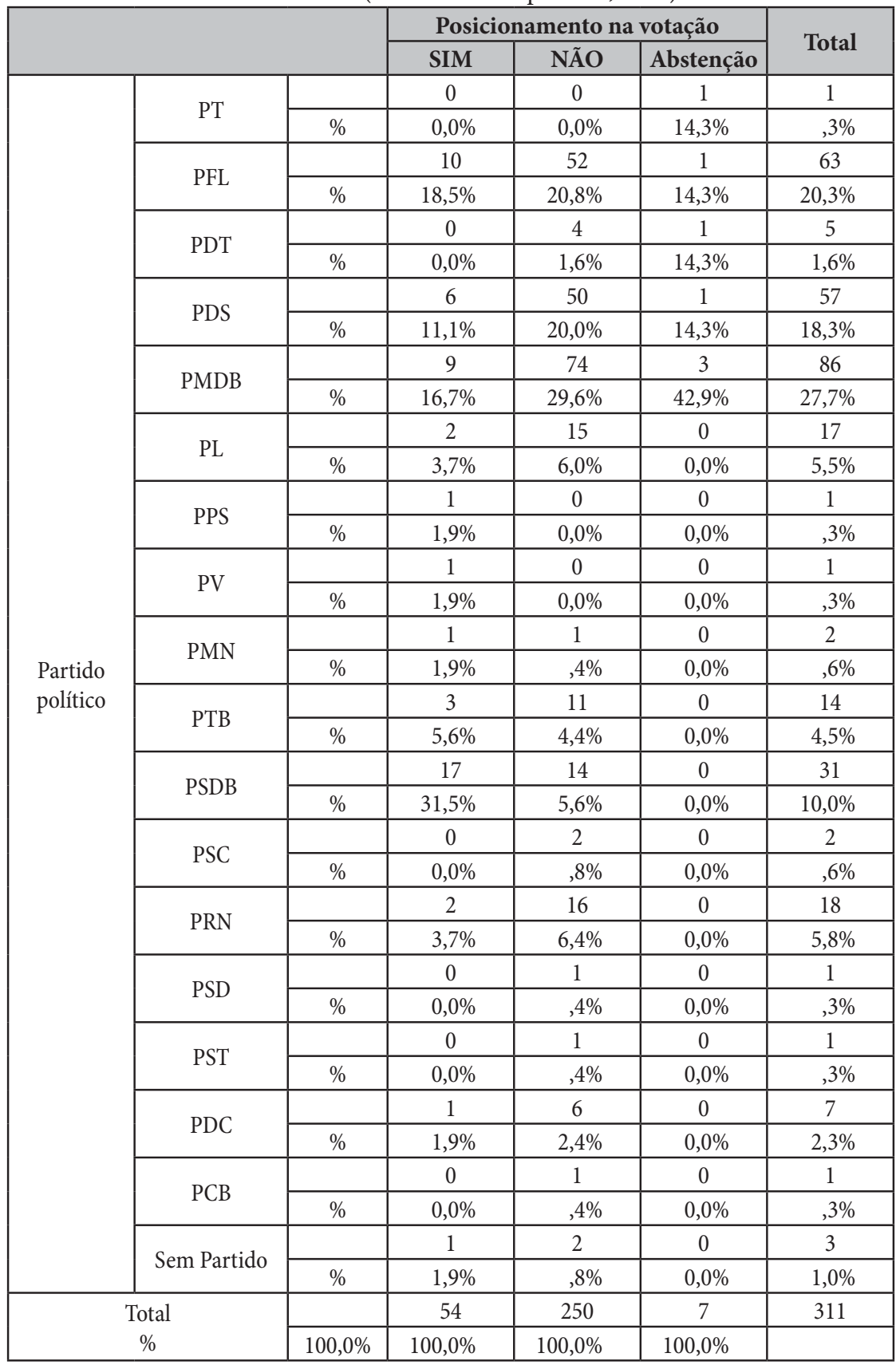


Tabela 10 - Revisão Constitucional (Câmara dos Deputados, 1994).

\begin{tabular}{|c|c|c|c|c|c|c|}
\hline & \multicolumn{3}{|c|}{ Posicionamento na votação } & \multirow{2}{*}{ Total } \\
\hline & & & SIM & NÃO & Abstenção & \\
\hline \multirow{8}{*}{$\begin{array}{l}\text { Ideologia } \\
\text { partidária }\end{array}$} & \multirow{2}{*}{ Esquerda } & & 3 & 6 & 2 & 11 \\
\hline & & $\%$ & $5,6 \%$ & $2,4 \%$ & $28,6 \%$ & $3,5 \%$ \\
\hline & \multirow{2}{*}{ Centro } & & 26 & 88 & 3 & 117 \\
\hline & & $\%$ & $48,1 \%$ & $35,2 \%$ & $42,9 \%$ & $37,6 \%$ \\
\hline & \multirow{2}{*}{ Direita } & & 24 & 152 & 2 & 178 \\
\hline & & $\%$ & $44,4 \%$ & $60,8 \%$ & $28,6 \%$ & $57,2 \%$ \\
\hline & \multirow{2}{*}{$\begin{array}{c}\text { Ideologicamente } \\
\text { indefinido }\end{array}$} & & 1 & 4 & 0 & 5 \\
\hline & & $\%$ & $1,9 \%$ & $1,6 \%$ & $0,0 \%$ & $1,6 \%$ \\
\hline \multirow{2}{*}{\multicolumn{2}{|c|}{$\begin{array}{c}\text { Total } \\
\%\end{array}$}} & & 54 & 250 & 7 & 311 \\
\hline & & $100,0 \%$ & $100,0 \%$ & $100,0 \%$ & $100,0 \%$ & \\
\hline
\end{tabular}

Fonte: Diário da Câmara dos Deputados

criminalização da homofobia. Observa-se também que os parlamentares dos partidos identificados como de direita passam a ser o segundo maior contingente de deputados apoiadores dos direitos LGBT com 27,3\% dos votos favoráveis (3 deputados) à PCR e 33,3\% dos favoráveis (19 deputados) à criminalização da homofobia (Tabela 12).

Se compararmos as assinaturas de proposições legislativas com a adesão à Frente Parlamentar pela Cidadania GLBT e as votações de projetos de lei que promovem os direitos sexuais de LGBT, observa-se um dado interessante. Nas décadas de 1990 e $2000^{33}$, há certo padrão de apoio à causa LGBT na Câmara dos Deputados. Os partidos de esquerda tendem a liderar a defesa dos direitos LGBT, com uma proporção de parlamentares variando entre 61,4\% (Adesão à Frente Parlamentar) e 43,9\% (votação da criminalização da homofobia), sendo seguidos pelos partidos de direita, com uma porcentagem de parlamentares apoiadores da temática LGBT variando entre 33,3\% (votação da criminalização da homofobia) e 20\% (Adesão à Frente Parlamentar) e pelos partidos de centro, com um percentual de apoio parlamentar entre 22,8\% (votação da criminalização da homofobia) e $14,7 \%$ (assinatura de proposições legislativas). Os dados demonstram que não há uma equivalência entre as clivagens ideológico-partidárias e os posicionamentos dos parlamentares em torno da questão dos direitos LGBT. Isso demonstra que a temática LGBT no Congresso Nacional logra apoio de partidos políticos de diferentes ideologias. Além das assinaturas de projetos de lei, da adesão à Frente Parlamentar GLBT e das votações favoráveis a propostas de legislação pró-LGBT, pode-se agregar o recente surgimento de setoriais LGBT em partidos de centro e de direita como demonstração do apoio plural que a temática LGBT tem ganhado atualmente no quadro partidário brasileiro.

${ }^{33}$ Excluiu-se a votação da Revisão Constitucional, por esta não ter contado com a presença dos parlamentares do PT. 
Tabela 11 - Parceria Civil Registrada - Comissão Especial (Câmara dos Deputados, 1996).

\begin{tabular}{|c|c|c|c|c|c|}
\hline & \multicolumn{2}{|c|}{$\begin{array}{c}\text { Posicionamento na } \\
\text { votação }\end{array}$} & \multirow[t]{2}{*}{ Total } \\
\hline & & & SIM & NÃO & \\
\hline \multirow{6}{*}{$\begin{array}{l}\text { Partidos por } \\
\text { ideologia }\end{array}$} & \multirow{2}{*}{ Esquerda } & & 6 & 0 & 6 \\
\hline & & $\%$ & $54,5 \%$ & $0,0 \%$ & $37,5 \%$ \\
\hline & \multirow{2}{*}{ Centro } & & 2 & 1 & 3 \\
\hline & & $\%$ & $18,2 \%$ & $20,0 \%$ & $18,8 \%$ \\
\hline & \multirow{2}{*}{ Direita } & & 3 & 4 & 7 \\
\hline & & $\%$ & $27,3 \%$ & $80,0 \%$ & $43,8 \%$ \\
\hline \multirow{2}{*}{\multicolumn{2}{|c|}{$\begin{array}{c}\text { Total } \\
\%\end{array}$}} & & 11 & 5 & 16 \\
\hline & & $100,0 \%$ & $100,0 \%$ & $100,0 \%$ & \\
\hline
\end{tabular}

Fonte: Comissão Especial, Câmara dos Deputados

Tabela 12 - Criminalização da homofobia - CCJ (Câmara dos Deputados, 2006) (34 $^{34}$

\begin{tabular}{|c|c|c|c|c|}
\hline \multicolumn{2}{|c|}{} & Frequência & $\mathbf{( \% )}$ & $\begin{array}{c}\text { Percentual } \\
\text { válido }\end{array}$ \\
\hline \multirow{3}{*}{$\begin{array}{c}\text { Partidos } \\
\text { políticos }\end{array}$} & Esquerda & 25 & 43,9 & 43,9 \\
\cline { 2 - 5 } & Centro & 13 & 22,8 & 22,8 \\
\cline { 2 - 5 } & Direita & 19 & 33,3 & 33,3 \\
\cline { 2 - 5 } & Total & 57 & 100,0 & 100,0 \\
\hline
\end{tabular}

Fonte: Comissão de Constituição e Justiça, Câmara dos Deputados

\section{Considerações finais}

O presente texto foi um esforço de elaborar uma radiografia de como a questão dos direitos LGBT tem sido contemplada pelos partidos políticos brasileiros nas últimas três décadas. A maior visibilidade pública do movimento LGBT, principalmente por meio das Paradas do Orgulho LGBT, vem se somar aos esforços de grupos de militância homossexual e ativistas individuais para sensibilizar a elite política brasileira da necessidade de se aprovar leis e regulamentos que defendam os direitos do segmento LGBT. Como visto ao longo do texto, o envolvimento prematuro do então Movimento Homossexual Brasileiro (MHB) com a política institucional não se converteu necessariamente na aprovação de leis pelo Legislativo nacional. Os poucos ganhos em termos de reconhecimento legal e de garantia de direitos foram alcançados em outras instâncias estatais (poderes Executivo e Judiciário). Mesmo com uma base de apoio relativamente plural do ponto de vista ideológico-partidário, o movimento LGBT não logrou avançar com sua agenda legislativa.

A oposição de setores conservadores adentro do Congresso Nacional tem sido importante para a rejeição de propostas de leis favoráveis as chamadas "minorias sexuais", a exemplo das votações da inclusão do termo "orientação sexual" na

${ }^{34}$ Inseriu-se uma tabela de frequência, pois a votação foi unânime em favor da aprovação do projeto de lei. 
cláusula antidiscriminatória da Constituição na ANC (1987 e 1988) e na Revisão Constitucional (1994). Mesmo nos casos em que se conseguiu a aprovação de projetos de lei favoráveis à população LGBT (como no caso da PCR em 1996 e da criminalização da homofobia em 2005), a ação de setores religiosos foi decisiva para a obstrução do trâmite destas propostas (Santos, 2011).

Se o cenário legislativo brasileiro é pouco promissor para as reivindicações do movimento LGBT, o âmbito partidário parece dar demonstrações de estar mais permeável às demandas desse segmento da população. Isso é fruto, em grande medida, da luta e da mobilização de ativistas LGBT dentro das agremiações partidárias ao longo destes anos. Mobilizações que, muitas vezes, geraram diversas tensões e conflitos no seio da militância homossexual, haja vista os diversos "rachas" ocorridos nos grupos do movimento organizado que tinham como uma das razões a questão da autonomia do movimento social frente aos partidos políticos. Se inicialmente a questão LGBT se restringia ao âmbito da esquerda, o que se observa recentemente é a maior pluralização da representação política desse segmento, com a presença de setoriais LGBT em partidos políticos que se localizam ao centro e à direta no espectro ideológico.

Essa maior pluralização da representação política de LGBT aponta para um traço característico das políticas sexuais no Brasil: não há uma equivalência direta entre as clivagens partidárias e a defesa nos direitos LGBT. Embora haja maior tendência de membros de partidos de esquerda a apoiarem a causa LGBT (dada à vinculação histórica do movimento LGBT com a esquerda partidária, principalmente com o PT, e ao apoio de parlamentares de esquerda às pautas "progressistas"), observa-se que vários membros de partidos de "direita" e de "centro" tanto votaram a favor de propostas de legislação favoráveis a LGBT quanto apresentaram propostas de leis favorável a esse segmento da população.

Nesse sentido, é preciso buscar outra variável para explicar a dificuldade em se aprovar legislações favoráveis à população LGBT. Embora não tenhamos dados suficientes para explorar tal hipótese, a observação das votações de projetos de lei pró-livre orientação sexual/identidade de gênero parece indicar que a vinculação religiosa dos parlamentares, majoritariamente daqueles que fazem parte da Frente Parlamentar Evangélica (FPE), parece ser relevante para explicar a oposição à extensão de direitos aos homossexuais do que sua vinculação partidária. Ao que parece, no Brasil, a clivagem religiosa desempenha importante papel para explicar a oposição aos direitos LGBT, já que as chamadas "questões morais" (aborto, descriminalização do uso de drogas e casamento entre pessoas do mesmo sexo) agregam os diferentes setores religiosos em oposição às chamadas pautas progressistas $^{35}$.

A maior participação de LGBT nos partidos políticos, não só por meio dos setoriais LGBT vinculados às estruturas organizacionais, mas também por meio das eleições, e a maior presença de suas reivindicações na política institucional,

\footnotetext{
${ }^{35}$ Para uma análise mais detalhada da atuação política dos evangélicos no Brasil, vide Campos Machado (2006).
} 
desponta como uma das principais transformações vivenciadas pela política brasileira neste princípio de século.

\section{Referências}

ALEXANDRO COLARES. Criação do setorial LGBT PSOL /AP. 2011. Disponível em: $<$ http://alexandrocolares.blogspot.com.br/2011/11/criacao-do-setorial-lgbt-psol-ap. html >. Acesso em: 29 nov. 2014.

ASSEMBLEIA NACIONAL CONSTITUINTE. Diário da Assembleia Nacional Constituinte (Suplemento “C”). Brasília, 1987, pp. 97-98.

. Diário da Assembleia Nacional Constituinte. Brasília, 1988, pp. 421-425.

ASSOCIAÇÃO BRASILEIRA DE LÉSBICAS, GAYS, BISSEXUAIS, TRAVESTIS E TRANSEXUAIS - ABGLT. Projeto Aliadas. 2014. Disponível em: <http://www.abglt. org.br/port/aliadas.php>. Acesso em: 29 nov. 2014.

BLOG WILLIAM DE LUCCA. Presidente da Diversidade do PSDB: "Dilma assinou compromisso com fundamentalistas evangélicos, enquanto o Serra, não. 2012. Disponível em: <http://deluccamartinez.wordpress.com/2012/03/24/presidente-da-diversidadedo-psdb-dilma-assinou-compromisso-com-fundamentalistas-evangelicos-enquantoo-serra-nao/>. Acesso em: 29 nov. 2014.

BOBBIO, Norberto. Direita e esquerda. São Paulo, Editora UNESP, 1995.

BÖER, Alexandre. Polêmica em Porto Alegre: capital gaúcha terá duas paradas gays este ano. Visão Real, 2005. Disponível em: <http://www.visaoreal.com.br/parada_gay_2_poa. htm>. Acesso em: 29 nov. 2014.

CÂMARA, Cristina. Cidadania e orientação sexual: a trajetória do grupo Triângulo Rosa. Rio de Janeiro, Academia Avançada, 2002.

CÂMARA DOS DEPUTADOS. Diário dos Trabalhos Revisionais. Brasília, Fevereiro de 1994, pp. 611-614.

. Comissão Especial. Sessão Deliberativa. 10 de dezembro. Aprovação do parecer do relator, Deputado Roberto Jefferson, pela constitucionalidade, juridicidade e técnica legislativa e, no mérito, pela aprovação do Projeto de lei 1151, com substitutivo. 50a Legislatura. Brasília, 1996. Disponível em: <http://www.camara.gov. br/proposicoesWeb/fichadetramitacao?idProposicao=.16329>. Acesso em: 29 abr. 2016.

. Plenário. Sessão Ordinária. 23 de novembro. 52a Legislatura - 4a Sessão Legislativa Ordinária. Brasília, 2006. Disponível em: <http://www.camara.gov.br/ internet/ordemdodia/ordemDetalheReuniaoPle.asp? codReuniao=13814>. Acesso em: 29 abr. 2016.

CAMPOS MACHADO, Maria das Dores. Política e religião: a participação dos evangélicos nas eleições. Rio de Janeiro, Editora FGV, 2006.

CARREIRÃO, Yan de Souza. Ideologia e partidos políticos: um estudo sobre coligações em Santa Catarina. Opinião Pública. Campinas, v. 12, n. 1, Abril/Maio 2006, pp. 136-163. 
CENTRAL DE NOTÍCIAS MIXBRASIL. Beto de Jesus se desliga da Parada do Orgulho GLBT de São Paulo. 2002a.

. Vice-presidente da Associação da Parada contesta versão de barraco em reunião da entidade. 2002 b.

CORADINI, Odaci Luiz. Frentes parlamentares, representação de interesses e alinhamentos políticos. Revista Sociologia e Política. Curitiba, v. 18, n. 36, Junho 2010, pp. 241-256.

DEHESA, Rafael de la. El sexo y la revolución: la liberación lésbico-gay y la izquierda partidaria en Brasil. Revista de Estudios Sociales. Colombia, n. 28, 2007, pp. 44-55.

DIVERSIDADE PTB. Nasce o $12^{\circ}$ Departamento petebista. 2010. Disponível em: <http:// ptbdiversidade.blogspot.com.br/2010/05/nasce-0-12-departamento-petebista-ptb_3798. html\#!/2010/05/nasce-o-12-departamento-petebista-ptb_3798.html>. Acesso em: 29 nov. 2014.

DOWNS, Anthony. Uma teoria econômica da democracia. São Paulo, Edusp, 1999.

DUVERGER, Maurice. Os partidos políticos. Brasília, Editora da UnB, 1980.

FACCHINI, Regina. Sopa de letrinhas? Movimento homossexual e produção de identidades coletivas nos anos 90. Rio de Janeiro, Garamond, 2005.

FIGUEIREDO, Argelina Cheibub; LIMONGI, Fernando. Executivo e legislativo na nova ordem constitucional. Rio de Janeiro, Editora FGV, 1999.

FRY, Peter. Para inglês ver: identidade e política na cultura brasileira. Rio de Janeiro, Zahar Editores, 1982.

GIACOMINI, Paulo. Gays pedem voto contra o preconceito. Folha de São Paulo, São Paulo, 15 jul. 1996.

GREEN, James Naylor. A luta pela igualdade: desejos, homossexualidade e a esquerda na América Latina. Cadernos AEL. Campinas, v. 10, n. 18-19, 2003, pp. 17-39.

. Além do carnaval: a homossexualidade masculina no Brasil do século XX. São Paulo, Editora UNESP, 2000.

GREEN, James Naylor; POLITO, R. Frescos trópicos: fontes sobre a homossexualidade masculina no Brasil (1870-1980), Rio de Janeiro, José Olympio, 2006.

GRUPO GAY DA BAHIA - GGB. Boletim do Grupo Gay da Bahia. Salvador, v. 2, Março 1982.

HISTÓRIA VERMELHA. Setorial LGBT petista realiza seminários para coordenadores estaduais. 2012. Disponível em: <http://historiavermelha.blogspot.com.br/2012/07/ setorial-lgbt-petista-realiza.html>. Acesso em: 29 nov. 2014.

INOVAGLTTB. Frente parlamentar mista pela livre expressão sexual. 2005. Disponível em: <http://inovaglttb.blogspot.com.br/2005/07/frente-parlamentar-mista-pela-livre. html $>$. Acesso em:29 nov. 2014.

KINZO, Maria. Radiografia do quadro partidário brasileiro. São Paulo, Fundação Konrad Adenauer, 1993.

MACRAE, Edward. A construção da igualdade: identidade sexual e política no Brasil da "abertura". Campinas, Editora da Unicamp, 1990. 
MAINWARING, Scott. Sistemas partidários em novas democracias: o caso do Brasil. Rio de Janeiro, Editora FGV, 1999.

MARENCO DOS SANTOS, A. Sedimentação de lealdades partidárias no Brasil: tendências e descompassos. Revista Brasileira de Ciências Sociais. São Paulo, v. 16, n. 45, Fevereiro 2001, pp. 69-83.

MASCARENHAS, João Antônio. Os homossexuais e a constituição federal. Jornal Nós Por Exemplo, março/abril 1994.

MELLO, Luiz. Novas famílias: conjugalidade homossexual no Brasil contemporâneo. Rio de Janeiro, Garamond, 2005.

MENEZES, Soraya. Lutando contra a discriminação sem medo de ser diferente. São Paulo: PSTU, 2002. Disponível em: <http://www.pstu.org.br/node/3357>. Acesso em: 29 nov. 2014.

MOTT, Luiz. Sexo proibido: virgens, gays e escravos nas garras da Inquisição. Campinas, Papirus, 1989.

NERY, Natuza; FALCÃO, Márcio. Líderes evangélicos cobram de Dilma 'carta à nação' sobre temas polêmicos. Folha de São Paulo, São Paulo, 13 out. 2010. Disponível em: $<$ http://www1.folha.uol.com.br/poder/813929-lideres-evangelicos-cobram-de-dilmacarta-a-nacao-sobre-temas-polemicos.shtml>. Acesso em: 29 nov. 2014.

OLIVEIRA, Rosa Maria Rodrigues. Direitos sexuais de LGBTTT no Brasil: jurisprudência, propostas legislativas e normatização federal. Brasília, Ministério da Justiça, 2012.

PARTIDO DA SOCIAL DEMOCRACIA BRASILEIRA - PSDB. PSDB fundará Diversidade Tucana no Piauí. São Paulo, 2012. Disponível em: <http://tucano.org.br/noticias-dopsdb/psdb-fundara-diversidade-tucana-no-piaui>. Acesso em: 29 nov. 2014.

PARTIDO DO MOVIMENTO DEMOCRÁTICO DO BRASIL - PMDB. Porto Alegre, 2013. Disponível em: <http://www.pmdbportoalegre.org.br/pdf/pmdb-diversidade.pdf >. Acesso em: 13 maio 2013.

PARTIDO SOCIALISMO E LIBERDADE - PSOL. 2014. Disponível em: <http://psol50. org.br/site/paginas/1/nossa-historia >. Acesso em: 29 nov. 2014.

PARTIDO SOCIALISTA BRASILEIRO - PSB. Caderno de orientações políticas do segmento LGBT socialista. Brasília, 2012. Disponível em: <http://www.psb40.org. br/downloads/lgbt/caderno_lgbt_orientacoes.pdf>. Acesso em: 29 nov. 2014.

PEREIRA, Carlos; MUELLER, Bernardo. Partidos fracos na arena eleitoral e partidos fortes na arena legislativa: a conexão eleitoral no Brasil. Dados: Revista de Ciências Sociais. Rio de Janeiro, v. 46, n. 4, 2003, pp. 735-771.

PORTAL VERMELHO. PCdoB lança coletivo e fortalece atuação no movimento LGBT. São Paulo, 2011. Disponível em: <http://www.vermelho.org.br/noticia. php?id_secao=8\&id_noticia=167559>. Acesso em: 29 nov. 2014.

RODRIGUES, Julian. Carta aberta à presidenta Dilma. Linha Direta, São Paulo, 26 maio 2011. Disponível em: <http://www.pt-sp.org.br/noticia/p/?id=4593>. Acesso em: 29 nov. 2014. 
RODRIGUES, Leôncio Martins. Partidos, ideologia e composição social: um estudo das bancadas partidárias na câmara dos deputados. São Paulo, Edusp, 2002.

SANTOS, Gustavo Gomes da Costa. Estado, projetos políticos e trajetórias individuais: um estudo com as lideranças homossexuais na cidade de São Paulo, Dissertação de mestrado, Ciência Política, Unicamp, 2006.

. Cidadania e direitos sexuais: um estudo comparativo do reconhecimento legal das uniões entre pessoas do mesmo sexo no Brasil e na África do Sul. Tese de doutorado, Ciência Política, Unicamp, 2011.

Sexual diversity and electoral politics: analysing transgender political candidacies in Contemporary Brazil. In: X IASSCS Conference. Dublin, Republic of Ireland, 2015.

SARTORI, Giovanni. Partidos e sistemas partidários. Brasília, Editora da UnB, 1982.

SEILER, Daniel-Louis. Os partidos políticos. Brasília, Editora UnB, 2000.

SENADO FEDERAL. Regimento Interno do Senado Federal: resolução n 93. Brasília, 1970. Disponível em: <https://www25.senado.leg.br/documents/12427/45868/RISFCompilado. pdf/cd5769c8-46c5-4c8a-9af7-99be436b89c4>. Acesso em: 29 abr. 2016.

SIMÕES, Júlio Assis; FACCHINI, Regina. Na trilha do arco-íris: do movimento homossexual ao LGBT. São Paulo, Editora Fundação Perseu Abramo, 2009.

SINDICATO DOS TRABALHADORES DA SAÚDE, TRABALHO E PREVIDENCIA SOCIAL DO ESTADO DO RIO DE JANEIRO - SINDSPREVRJ. Setorial LGBT do PSOL debate na segunda-feira (19/09) o tema 'casamento igualitário'. Rio de Janeiro, 2011. Disponível em: $<\mathrm{http} / /$ www.sindsprevrj.org.br/jornal/secao.asp?area=24\&entrada=5210 $>$. Acesso em: 12 maio 2013.

SINGER, Andre. Esquerda e direita no eleitorado brasileiro. São Paulo, Edusp, 1999.

TREVISAN, João Silvério. Devassos no paraíso: a homossexualidade no Brasil, da colônia à atualidade. 6. ed. Rio de Janeiro, Record, 2004.

UOL. Em cerimônia na Assembleia Legislativa de São Paulo, PSOL lança seu Setorial LGBT. Mix Brasil, 19 nov. 2011. Disponível em: <http://mixbrasil.uol.com.br/pride/ politica/com-presenca-de-deputados-friendly-psol-lanca-seu-setorial-lgbt-em-saopaulo.html>. Acesso em: 12 maio 2013.

Recebido em: 20/08/2015

Aprovado em: 20/02/2016

\section{Como citar este artigo:}

SANTOS, Gustavo Gomes da Costa. Movimento LGBT e partidos políticos no Brasil. Contemporânea - Revista de Sociologia da UFSCar. São Carlos, v. 6, n. 1, jan.-jun. 2016, pp. 179-212. 